\title{
Hydrogeochemical evolution and groundwater quality assessment using chemical systematics, statistical techniques, and pollution index of groundwater (PIG): a case study
}

Vandi Dlama Kamaunji ( $\square$ vandikamaunji@cug.edu.cn )

China University of Geosciences https://orcid.org/0000-0002-2717-9894

Jackson Makpane Ishaku

Modibbo Adama University of Technology

Dlama Zira Kamaunji

Ministry of Mineral Resources Headquarters, Yola

Ibrahim Abdulkarim Kwami

Gombe State University

\section{Research Article}

Keywords: Hydrogeochemistry, Pollution index of groundwater, Multivariate statistical analysis, Drinking water

Posted Date: March 24th, 2021

DOI: https://doi.org/10.21203/rs.3.rs-268342/v1

License: (c) (1) This work is licensed under a Creative Commons Attribution 4.0 International License.

Read Full License 


\title{
Hydrogeochemical evolution and groundwater quality assessment using chemical systematics, statistical techniques, and pollution index of groundwater (PIG): a case study
}

\author{
Vandi Dlama Kamaunji ${ }^{a *}$, Jackson Makpane Ishakub ${ }^{\text {, Dlama Zira Kamaunji }}$, Ibrahim \\ Abdulkarim Kwami ${ }^{\text {d }}$ \\ ${ }^{a}$ State Key Laboratory of Geological Processes and Mineral Resources, School of Earth Sciences, China \\ University of Geosciences, 430074, Wuhan, P.R. China \\ ${ }^{b}$ Department of Geology, School of Physical Sciences, Modibbo Adama University of Technology, P.M.B. \\ 2076, Yola, Nigeria \\ ${ }^{c}$ Ministry of Mineral Resources Headquarters, P.M.B. 2012, Yola, Adamawa State, Nigeria \\ ${ }^{d}$ Department of Geology, Gombe State University, P.M.B. 0127, Gombe, Nigeria \\ *= Corresponding author. Tel: +86 15623282689. Email: vandikamaunji@.cug.edu.cn (V.D. Kamaunji)
}

\begin{abstract}
Herein, we investigate the hydrogeochemical processes influencing the chemistry and suitability of groundwater for drinking in Mubi south area, north-eastern Nigeria based on physicochemical results of water samples collected from 30 boreholes in the area. The cations and anions distribution in the samples are in the order $\mathrm{Mg}^{2+}>\mathrm{K}^{+}>\mathrm{Na}^{+}$and $\mathrm{HCO}_{3}{ }^{-}>\mathrm{NO}_{3}{ }^{-}>\mathrm{Cl}^{-}>\mathrm{SO}_{4}{ }^{2-}>\mathrm{CO}_{3}{ }^{2-}$ respectively. The low turbidity $(0.02-$ 4.86 NTU) and neutral-mildly alkaline nature $(\mathrm{pH}=6.65-8.70)$ of the groundwater indicate high clarity, low level of cloudiness, high $\mathrm{CO}_{2}$ abundance and dissolve ions in form of $\mathrm{HCO}_{3}{ }^{-}$. Hydrogeochemical (e.g., Piper, Durov, bi-variant and scatter plots) and statistical (PCA and HCA) evidences highlight the biogeochemical hydrolysis (i.e. silicate weathering) of silicate minerals (such as K-feldspars, pyroxenes, amphiboles) as the major process controlling the groundwater chemistry. The dominance of $\mathrm{Ca}^{2+}-\mathrm{Mg}^{2+}-\mathrm{HCO}_{3}{ }^{-}$water type, coupled with the strong positive correlation between $\mathrm{EC}$ and $\mathrm{K}^{+}(\mathrm{r}=0.75)$, and the strong positive loading of $\mathrm{Ca}^{+}(0.74)$ are robust evidences for the silicate weathering process. However, the elevated $\mathrm{Cl}^{-}$concentrations (15-206 mg/l), and the insignificant variation of $\mathrm{Na}^{+} / \mathrm{Cl}^{-}$ratio with increasing $\mathrm{EC}$ as well as the high positive loadings of EC and TDS imply other secondary processes (e.g., evaporate salts and anthropogenic pollution) were also involved in the hydrogeochemical evolution. The pollution index of groundwater (PIG $=0.27-$ 0.737) fall below the insignificant pollution state of less than 1, diagnostic of good water quality for drinking purpose and sustainability of public health.
\end{abstract}

Key words: Hydrogeochemistry; Pollution index of groundwater, Multivariate statistical analysis; Drinking water. 
Groundwater is invariably the main source of fresh water essential to life globally (Foster and Chilton, 2003). Sufficient groundwater quantity with good quality is necessary for the increasing household and

37 agricultural needs. Typically, groundwater is clear and colorless with constant temperature. Groundwater is 38 preferentially used for many purposes due to the presence of dissolved minerals and some peculiar 39 characteristics as compared with the surface water (e.g., Rajankar et al., 2009; Kulinkina et al., 2017). Most 40 communities especially in the rural areas often use groundwater without proper treatment which makes it 41 hazardous to public health in cases of elevated content of undesirable elements, most of which exist primarily 42 due to the hydrogeochemical processes. Chemical reactions during this process can greatly affect the potency 43 of some elements since precipitated elements are less hazardous than mobile elements. Therefore, the degree 44 to which these mobile elements affect groundwater quality depends mainly on the chemical species, 45 characteristics, and concentration of the elements (e.g., Mapoma et al., 2017). The variable compositions of 46 these elements in groundwater are largely controlled by natural and anthropogenic activities. The influence 47 of the latter process either pollute the groundwater or change the hydrological cycle (e.g., Helena et al., 2000).

48 A plethora of researchers (e.g., Chilton and Foster, 1995; Chimphamba et al., 2009; Pietersen 2009; 49 Walraevens et al., 2018; Oyedele et al., 2019) consented that most groundwater quality in basement aquifers 50 are within the satisfactory pollution state, owing to the low level of mineralizations and low solubility of the 51 aquifer-forming materials. However, the heterogeneity of basement aquifers as a result of the complex and 52 spatial variations of the hydrochemical parameters even within a short distance is highly problematic (e.g., 53 Foster and Chilton, 1995; Tarits et al., 2006; Stober and Bucher, 2015). For example, some studies revealed 54 poor water quality associated with elevated sulphate content during anhydrite dissolution or sulphide 55 minerals in basement aquifers (e.g., Akiwumi, 1997; Reuschel et al., 2012). Additionally, elevated trace 56 element contents in reduced and acidic environment such as mine site is highly detrimental to groundwater 57 in basement aquifers (e.g., Kortatsi et al., 2008; Doumas et al., 2018). Similarly, high salinity due to evaporate 58 salts leaching and upward injection of saline waters in faulted areas can also influence groundwater quality 59 (e.g., Williams et al., 2013; Mapoma et al., 2014; Walraevens et al., 2015).

60 The study area lies wholly within the Hawal Massif, which, together with the Adamawa Massif and 61 Oban Massif constitute the Eastern Nigerian Basement Complex that extend into the Cameroon Republic 62 (Fig. 1). The area is underlain by migmatite-gneiss complex, which are discordantly intruded by the Pan- 
63 African Older granites and their extrusive volcanic equivalents, most of which are overlain by alluvial

64 deposits. These rocks are frequently exploited for groundwater through borehole drilling and hand-dug wells.

65 However, artisanal mining of monazite in the east-central part of the area, coupled with intensive agricultural

66 practices involving uncontrolled fertilizer and manure applications could exacerbate the mobility of trace

67 elements (Romic and Romic, 2003; Monged et al., 2020). These activities may also exert enormous pressure

68 on water quality and availability (Foster et al., 2013; Chen et al., 2017; du Plessis, 2019). This brings to fore

69 the need to critically examine the chemistry and quality of groundwater in the area for the sustainability of 70 public health.

71 Understanding the hydrogeochemistry of groundwater is a crucial step for long-term borehole water

72 quality assessment. In this contribution, we present physicochemical constituents of groundwater within the

73 basement aquifers in Mubi South area, north-eastern Nigeria. We evaluated the important hydrogeochemical

74 processes controlling groundwater chemistry in 30 selected boreholes from a combined hydrochemical

75 concepts (e.g., Piper, Durov, bi-variant and scatter plots), and multivariate statistical analysis points of view.

76 Importantly, groundwater suitability for drinking was evaluated based on pollution index of groundwater 77 (PIG).

\section{2. Geologic setting}

$79 \quad 2.1$ Local geology

80 Geologically, Mubi south area in northern Adamawa State, north-eastern Nigeria is composed of 81 undifferentiated migmatitic-gneisses, Pan-African Older Granites, granite-gneisses, amphibolites, basalts, 82 rhyolites and alluvial deposits. The Pan-African granites occur as highly rugged hills in the central, north83 eastern and eastern part of the area, but are low-lying in the northwest (Fig. 2). They are characterized by 84 alternating bands of closely spaced medium to coarse-grained leucocratic and melanocratic mineral 85 assemblages of platy biotite markedly discernable from the light-colored quartz and dominant feldspars.

86 Undifferentiated migmatitic-gneisses occur as steeply dipping hills in the southeastern and northern parts of 87 the area (Fig. 2). These rocks are coarse-grained with leucocratic quartzo-feldspartic crystals well interlocked 88 within the dark-colored biotites.

89 The granite-gneisses are characterized by conspicuous dark bands of minerals embedded in a medium90 grained mass of light-colored quartz and feldspars and are intrusive into the migmatitic-gneisses (Fig. 2). The 
91 amphibolites are of restricted occurrences well exposed in a blasted quarry. The rock mass is characterized

92 by essentials of dark colored minerals and tiny specks of quartzofeldspathic crystals. Rhyolites and basalts

93 are light- and dark colored respectively well exposed within the southwestern extremity of the study area,

94 some of which outcropped as small rounded hills. These volcanic rocks probably represent volcanic remnants

95 from the adjacent Cameroon Volcanic line (CVL). The granitic rocks in the NE, NW and SW are overlain

96 by alluvium and eluvium constituting mainly of sands, silts, gravels, clays and reddish laterites which serves

97 as targets for some boreholes and shallow hand-dug wells in the area.

98

99

100

101

102

103

104

105

106

107

108

109

110

111

112

113

114

115

116

117

118

119

\subsection{Hydrology and hydrogeology}

The occurrence of water resources, its extraction, uses and chemical quality and quantity define the scope of hydrogeology and entails both the surface water and groundwater potentials of the area. The Mubi area is characterized by high mean annual rainfall $(1050 \mathrm{~mm})$, with an early mean onset date of rain $\left(10^{\text {th }}\right.$ May), late mean cessation dates of rain $\left(16^{\text {th }}\right.$ to $20^{\text {th }}$ October), and long duration of mean rainy season (about 160 to 170 days, Fig. 3). Unfortunately, there are no facilities that can store the excess overflow of the abundant surface water. Nonetheless, its underflow is exploited through the construction of boreholes and hand-dug wells into the alluvium and weathered/fractured basement to carter for the increasing household, agricultural and livestock needs of the people.

Hydrogeologically, fresh crystalline basement rocks in the area, akin to any other basement complexes hardly any groundwater potential and flow. Groundwater in the area occur within a wide range of secondary porosities and permeabilities which were developed as a result extensive fracturing, jointing, shearing and deep weathering (Jones, 1985; Boutt et al., 2010). These structures and weathering profile are evidenced by the litho-logs from boreholes in the area and the results of integrated (electromagnetic and resistivity) geophysical investigation which was conducted prior to groundwater sampling. These network of fractures and weathered regoliths supply moderate groundwater to boreholes in the area. Variations in groundwater yield at different location within these zones is mainly controlled by the nature of bedrock, fracture and weathering intensity and density (Banks et al., 2009; Guihéneuf et al., 2014).

The crystalline basement aquifers are recharged through infiltration from the upper levels of the saturated weathered regolith (Holland, 2011), consisting of collapsed zone (laterites, illuviated clay and stone lines) and saprolite zone (weathered and disaggregated domain) (Figs. 5a-b; Wright, 1992). Field studies have shown that variable thickness of the weathered regoliths, coupled with the variations in groundwater potential 
120 at different zones in the area are controlled by the contrasting distribution pattern of the rock types, their 121 mineralogical assemblages and differential degree of weathering. The saprock region (weathered bedrock) is

122 characterized by sharp or transitional boundary against coarse-grained massif rocks or fine-grained rocks

123 (Figs. 5a-b). Fracture permeability within the saprock zone often increases due to weathering (unlike in the 124 fresh bedrock) unless it is filled with illuviated clay materials (Wright, 1992; Anand and Paine, 2002). The 125 water table in the study area probably occurs at shallow levels (less than 10-15 m) due in part to the moderate126 high annual rainfall (>600 mm per annum; e.g., Wright, 1992) (Fig. 3a).

\section{3. Materials and Methods}

$128 \quad 3.1$ Groundwater sampling and analysis

129 Thirty community boreholes in Mubi South area were targeted during the peak of dry season (late March, 130 2017). Preliminary analyses of the selected groundwater points included field in-situ measurements of the 131 physical parameters. The $\mathrm{pH}$ and temperature were measured using Pen $\mathrm{pH} /$ Temperature Meter (Model 132 CT6021). The electrical conductivity (EC) was determined using Pen conductivity meter (model CT306) 133 while the total dissolved solids (TDS) was measured using pen TDS meter (Model 21000). Carbonate $\left(\mathrm{CO}_{3}^{-}\right)$ 134 and bicarbonate $\left(\mathrm{HCO}_{3}^{-}\right)$were measured using trimetric method ( $\mathrm{HACH}$ digital titrator 16900$)$. Coordinates 135 of sample locations was recorded using GPS (Global positioning system and adequately marked on the 136 hydrogeologic map of the area.

137 Groundwater samples for laboratory studies were filtered through a $0.45 \mu \mathrm{m}$ filter into an already pre138 washed and pre-labeled 1 liter polythene bottle and triple rinsed prior to sampling from boreholes after 30 139 seconds of pumping, provided no one was fetching the water. If the borehole was rarely used, it was pumped 140 for about 2 minutes prior to collection. During groundwater sampling, quality assurance and control was 141 achieved following the procedures in the Water Quality Sampling Manual (APHA, 2012). Accuracy of 142 sample labelling and the use of standard solutions which ensured the precision and accuracy as well as 143 reproducibility of the results was based on Taiwo et al. (2015). The sampled groundwater was controlled 144 using $3 \mathrm{ml}$ analytical-grade nitric acid $\left(\mathrm{HNO}_{3}\right)$ until a standard $\mathrm{pH}$ of 2 was achieved. The acidification was 145 done in order to stabilize the water and further prevent precipitation of metals. All the samples were preserved 146 in a refrigerator at a temperature below $4{ }^{\circ} \mathrm{C}$ in order to stop the metabolism and activities of organisms before 147 the analysis at the laboratory. 
149 Headquarters, Yola using the spectrophotometer (Model HACH DR 2000) at specified (error range) 150 wavelength (APHA, 2012). Chemical parameters analyzed include calcium $\left(\mathrm{Ca}^{2+}\right)$, magnesium $\left(\mathrm{Mg}^{2+}\right)$,

151 sodium $\left(\mathrm{Na}^{2+}\right)$, potassium $\left(\mathrm{K}^{+}\right)$, sulphate $\left(\mathrm{SO}_{4}{ }^{2-}\right)$, chloride $\left(\mathrm{Cl}^{-}\right)$, nitrate $\left(\mathrm{NO}_{3}{ }^{2-}\right)$, fluoride $\left(\mathrm{F}^{-}\right)$, iron $\left(\mathrm{Fe}^{2+}\right)$, 152 manganese $\left(\mathrm{Mn}^{2-}\right)$, copper $\left(\mathrm{Cu}^{2+}\right)$, total hardness $\left(\mathrm{TH}, \mathrm{CaCO}_{3}\right)$, zinc $\left(\mathrm{Zn}^{2+}\right)$, phosphate $\left(\mathrm{PO}_{4}{ }^{2-}\right)$, hydrogen 153 Sulfide $\left(\mathrm{H}_{2} \mathrm{~S}\right)$, cyanide $(\mathrm{CN})$, Arsenic $(\mathrm{As})$, cadmium $\left(\mathrm{Cd}^{2+}\right)$, Lead $\left(\mathrm{Pb}^{2+}\right)$ and chromium $\left(\mathrm{Cr}^{6+}\right)$. However, six 154 of the parameters $\left(\mathrm{H}_{2} \mathrm{~S}, \mathrm{CN}, \mathrm{Cr}, \mathrm{Cd}, \mathrm{As}\right.$, and $\left.\mathrm{Pb}\right)$ has been excluded from the list because they were below 155 detection limit. Quality assurance and control during water analysis was achieved following the Standard 156 Methods for the Examination of Water and Wastewater (APHA, 2012), and the use of laboratory blanks and 157 calibration standards. The accuracy in the measurements of ions was confirmed through the estimation of 158 ionic balance errors, the results of which of fall within the acceptable range of $\pm 5 \%$.

\subsection{Hydrochemical Evolution}

\subsubsection{Hydro-geochemical facies and processes}

161 The grouping of hydrochemical facies on Piper diagram is based on the important ions that contributed 162 in the chemistry of groundwater (Piper, 1944). The diagram was plotted using AQqa computer software (v. 163 1.5) and graphically demonstrates the chemical equilibrium between the prominent cations (e.g., $\mathrm{Ca}^{2+}, \mathrm{Mg}^{2+}$, $164 \mathrm{Na}^{+}$and $\mathrm{K}^{+}$) and major anions (e.g., $\mathrm{Cl}^{-}, \mathrm{SO}_{4}{ }^{2-}, \mathrm{CO}_{3}{ }^{2-}$ and $\left.\mathrm{HCO}_{3}{ }^{-}\right)$. The Piper diagram constitutes two triangles 165 of the prominent cations and anions, and a quadrilateral (diamond shape) at the middle showing the ions 166 distribution and their associated water types.

167 A similar diagram known as Durov diagram (Durov, 1948) was also plotted using AQqa software (v. 168 1.5). This diagram shows the main anions and cations as percentages (in meq/l) in two ternary graphs where 169 these ions are plotted. A middle square graph bounded to both triangles illustrates the processes influencing 170 groundwater chemistry. For each sample, the sum total of ions in both triangles is $100 \%$. Verification of the 171 Kaiser-Meyer-Olkin (KMO) sample adequacy measure and Bartlett's Sphericity Test was done using SPSS 172 v.16. The result is adequate if KMO value is greater than 0.5 (Kaiser, 1974; Field, 2000). Bartlett's Sphericity 173 Test with significant value less than 0.05 implies that the factor analysis data is normal and acceptable (Field, 174 2000; Pallant, 2013). The KMO adequacy value (0.689; Table 1) of the data exceeds the standard value of 1750.5 , indicating adequacy and acceptability of the results. Similarly, Bartlett's Sphericity Test yielded a 
176 significant value of 0.000 (Table 1), which is less than the recommended value of 0.05 , indicating that the

177 data is normal and acceptable for factor analysis.

$178 \quad 3.2 .2$ Ion-exchange process in the aquifers

179 The ion-exchange processes occurring between the groundwater and host aquifer during residence time 180 is represented by the chloro-alkaline indices I and II:

releases $\mathrm{Na}^{2+}$ ions. The $\mathrm{Na}^{2+}$ and $\mathrm{K}^{+}$are replaced by $\mathrm{Mg}^{2+}$ and $\mathrm{Ca}^{2+}$ ions. As such, positive values are indicative of base-exchange while negative values represent chloro-alkaline disequilibrium. During this process, the dissolved solids likely originated from the host aquifers (cf. Schoeller, 1967). associated with total dissolved solids was employed (cf. Gibbs, 1970). The diagram illustrates the influence of various hydrogeochemical processes (e.g., precipitation, evaporation and rock-water interaction) on groundwater chemistry. Gibbs ratio is computed from the relation:

$$
\text { Gibbs ratio I (for anion): } \quad \frac{\mathrm{Cl}}{\mathrm{Cl}+\mathrm{HCO}_{3}}
$$

$$
\text { Gibbs ratio II (for cations): } \quad \frac{\mathrm{Na}+\mathrm{K}}{\mathrm{Na}+\mathrm{K}+\mathrm{Ca}}
$$

Notably, the processes associated with rock-water interaction include chemical weathering, dissolution

196 minerals (Gibbs, 1970).

\subsection{Multivariate statistical analysis}

Multivariate statistical analysis is primarily employed for data reduction to examine the possible source(s) of elements as well as the different chemical factors controlling them (cf. MacGregor and Kourti,

200 1995). The IBM $₫$ SPSS $₫$ computer software (v. 16) was utilized for the multivariate analysis of the 201 hydrochemical data set. Rotated component matrix was generated and principal component analysis and 
Kaiser Normalization varimax were selected as extraction and rotated methods respectively. During

203 hierarchical cluster analysis, dendrogram was extracted using ward's method with a combine rescaled

204 distance cluster. For the factor analysis (FA) of the data set, Pearson's correlation using two-tailed

205 significance was used.

\subsection{Groundwater quality for drinking}

\subsubsection{Pollution index of groundwater (PIG)}

Pollution index of groundwater (PIG) is an important numerical scale developed by Subba Rao (2012).

209 It quantifies the degree of contamination and has been successfully employed in the evaluation of the 210 variations in groundwater quality for drinking purpose (e.g., Elumalai et al., 2017; Subba Rao et al., 2018;

211 Chaturvedi et al., 2019; Subba Rao and Chaudhary, 2019; Adimalla et al., 2020; Egbueri, 2020). In assessing

212 the groundwater quality for drinking based using the PIG technique, five steps were taken.

213 Firstly, a relative weight $(\mathrm{Rw})$ was allotted for each of the analyzed physical and chemical parameters

214 of the groundwater on a numerical scale of 1 to 5 , taking into consideration their relative significance in

215 groundwater quality evaluation and effects on human health. Accordingly, Relative weight (Rw) of 5 was

216 assigned to most important parameters such as $\mathrm{pH}, \mathrm{TDS}, \mathrm{NO}_{3}{ }^{2-}, \mathrm{SO}_{4}{ }^{2-}$, and $\mathrm{F}^{-}$, while $\mathrm{HCO}_{3}^{-}$, which is the next

217 important parameter was assigned a relative weight $(\mathrm{Rw})$ of 3 . Calcium $\left(\mathrm{Ca}^{2+}\right)$ and $\mathrm{Mg}^{2+}$ were allotted a

218 relative weight $(\mathrm{Rw})$ of 2 . Potassium $\left(\mathrm{K}^{+}\right)$, being the least significant parameter was assigned a minimum 219 weight of 1.

220 Secondly, the weight parameter (Wp) for each of the groundwater quality variables was calculated to

221 evaluate their relative significance on the overall water quality. The weight parameter (Wp) is the ratio of 222 relative weight $(\mathrm{Rw})$ of each water quality parameter divided by the summation of all the relative weights

$223(\mathrm{Rw})$ (Equation 5):

$$
W p=\frac{\mathrm{Rw}}{\Sigma \mathrm{Rw}}
$$

The third step involved status of concentration (Sc) estimation for each groundwater sample in relation 226 to the quality standards of each variable. To calculate Sc of sample, the concentration (C) of each parameter 227 was divided by their respective permissible quality standards (Ds). Of note, the permissible standards of the 228 World Health Organization (WHO, 2017) and Canadian drinking water quality (GCDWQ, 2007) was 229 adopted in the PIG evaluation. The latter was used specifically for $\mathrm{HCO}_{3}{ }^{2-}$. 
The fourth step involved calculation of the overall water quality $(\mathrm{Ow})$ of each variable. This was 232 achieved by multiplying the weight parameter (Wp) with its corresponding status of concentration (Sc) 233 (Equation 7).

$$
\mathrm{Ow}=\mathrm{Wp} \times \mathrm{Sc}
$$

In the final step, the pollution index of groundwater (PIG) was quantified by adding all the overall water quality $(\mathrm{Ow})$ values of each variable in every groundwater sample $(\Sigma \mathrm{Ow})$ :

$$
\mathrm{PIG}=\Sigma \mathrm{Ow}
$$

The pollution index of groundwater (PIG) reflects the relative contributions of all the physical and chemical parameters of each water sample, thus, indicates the different conditions of physicochemical

240 contamination on the host aquifer (e.g., Subba Rao, 2012; Subba Rao et al., 2018; Subba Rao and Chaudhary, 241 2019). Pollution index of groundwater $(\mathrm{PIG})<1$ is interpreted as insignificant pollution, 1 to 1.5 is considered 242 as low pollution, 1.5 to 2 is regarded as moderate pollution, 2.0 to 2.5 is interpreted as high pollution, and > 2432.5 is interpreted as very high pollution (Subba Rao, 2012).

\section{4. Results and Discussion}

2454.1 Hydrogeochemical profile

246 Table 2 shows the physical/organoleptic field measurements of groundwater samples, whereas the 247 results of hydrochemical analyses are presented in Table 3. The overall summary of physicochemical 248 parameters and their respective permissible standards are shown in Table 4. Notably, standards for 249 bicarbonate $\left(\mathrm{HCO}_{3}^{-}\right)$and zinc $(\mathrm{Zn})$ are based on Guidelines for Canadian drinking water quality (GCDWQ, 250 2007) and Nigerian Standard for Drinking Water Quality (NSDWQ, 2015) respectively. Temperature and $251 \mathrm{pH}$ range from 23.62 to $29.00^{\circ} \mathrm{C}\left(\right.$ average, $27.1^{\circ} \mathrm{C}$.) and 6.65 to 8.70 (average $=7.73$ ) respectively whereas 252 EC and TDS range from 27 to $570 \mu \mathrm{s} / \mathrm{cm}$ (average $=198.4 \mu \mathrm{s} / \mathrm{cm})$ and 87 to $382 \mathrm{mg} / \mathrm{l}($ average $=150.23$ $253 \mathrm{mg} / \mathrm{l}$ ) respectively (Table 4). All the measured parameters are within the WHO allowable limits. The 254 temperature is reflective of the average temperature of air at the time of groundwater sampling. The $\mathrm{pH}$ values 255 indicate a neutral to mildly alkaline affinity for the studied groundwater. Because temperature and $\mathrm{pH}$ are 256 highly influential during dissolution of minerals in groundwater, the estimated $\mathrm{pH}$ average value of 7.57 is 

of $\mathrm{HCO}_{3}^{-}$(Freeze and Cherry, 1979). The low TDS values indicate low mineralized groundwater with a

259 limited history of migration and water-rock interactions (Talabi and Tijani, 2013). The turbidity values vary from 0.02 to 4.86 NTU with an average of 1.52 NTU and falls within the 5 NTU guideline (WHO, 2017), implying a high level of clarity and low level of cloudiness and murkiness.

Calcium $\left(\mathrm{Ca}^{2+}\right)$ is the dominant cations and display the highest concentration $(27.63$ to $71.00 \mathrm{mg} / \mathrm{l}$, average $=41.84 \mathrm{mg} / \mathrm{l})$ in the studied groundwater, followed by $\mathrm{Mg}^{2+}$ with concentrations ranging from 18.67 to $66.12 \mathrm{mg} / \mathrm{l}$ (average $=42.40 \mathrm{mg} / \mathrm{l})$. The higher concentration of $\mathrm{Ca}^{2+}$ relative to $\mathrm{Mg}^{2+}$ probably indicate the release of excess $\mathrm{Ca}^{2+}$ from weathering of Ca-bearing silicate minerals such as $\mathrm{K}$-feldspars, pyroxenes and amphiboles. The alkali metals display relatively low concentrations $\left(\mathrm{Na}^{+}=0.49\right.$ to $6.85 \mathrm{mg} / \mathrm{l}$, average $=$ $1.87 \mathrm{mg} / \mathrm{l} ; \mathrm{K}^{+}=6$ to $12 \mathrm{mg} / \mathrm{l}$, average $=8.55$ ), much lower than their permissible standards of $200 \mathrm{mg} / \mathrm{l}$ and $30 \mathrm{mg} / \mathrm{l}$, respectively (Table 4). The dominant anion in the groundwater is bicarbonate $\left(\mathrm{HCO}_{3}^{-}\right)$, with concentrations ranging from 189 to $367 \mathrm{mg} / \mathrm{l}$ (average $=238 \mathrm{mg} / \mathrm{l}$ ), followed by $\mathrm{Cl}^{-}$( 15 to $206 \mathrm{mg} / \mathrm{l}$, average $=33.56 \mathrm{mg} / \mathrm{l}), \mathrm{NO}_{3}{ }^{2-}(12.83$ to $99.7 \mathrm{mg} / \mathrm{l}$, average $=35.93 \mathrm{mg} / \mathrm{l}), \mathrm{SO}_{4}{ }^{2-}(10.52$ to $43.07 \mathrm{mg} / \mathrm{l}$, average $=22.15$

$271 \mathrm{mg} / \mathrm{l}), \mathrm{CO}_{3}{ }^{2-}(0$ to $5.1 \mathrm{mg} /$, average $=1.13 \mathrm{mg} / \mathrm{l})$, and $\mathrm{F}^{-}(0$ to $0.29 \mathrm{mg} / \mathrm{l}$, average $=0.064 \mathrm{mg} / \mathrm{l})($ Table 2$)$. All 272 the anion concentrations are within the WHO (2017) permissible guidelines (See Table 4).

273 The studied groundwater samples display Total Hardness (TH) concentration between 51.67 to 146.12 $274 \mathrm{mg} / \mathrm{l}$ with an average of $75.91 \mathrm{mg} / \mathrm{l}$ (Table 3). Based on the Canadian drinking water quality hardness (Health 275 Canada, 2012), water with $\mathrm{TH}$ (in form of $\mathrm{CaCO}_{3}$ ) $<60 \mathrm{mg} / \mathrm{l}$ is regarded as soft, while 60 to $120 \mathrm{mg} / \mathrm{l}$ is 276 interpreted as medium hard. Total Hardness (TH) between 120 to $180 \mathrm{mg} / \mathrm{l}$ is interpreted as hard, and >180 $277 \mathrm{mg} / \mathrm{l}$ is interpreted as very hard. Based on this guidelines, the studied groundwater (average $\mathrm{TH}=75.91 \mathrm{mg} / \mathrm{l}$ ) 278 can be interpreted as soft to medium hard. Moreover, $17 \%$ of the water samples display $\mathrm{TH}<50$ while $83 \%$ 279 range from 60 to $120 \mathrm{mg} / \mathrm{l}$, all of which are within the WHO permissible standard of $500 \mathrm{mg} / \mathrm{l}$ (Table 4). The 280 medium hardness portrayed by majority of the groundwater could be due to weathering of $\mathrm{Ca}^{2+}$ rich minerals 281 in the crystalline bedrocks.

282 The contents of cations and anions in the studied groundwater are within the range of $\mathrm{Ca}^{2+}>\mathrm{Mg}^{2+}>$ $283 \mathrm{~K}^{+}>\mathrm{Na}^{+}$and $\mathrm{HCO}_{3}{ }^{-}>\mathrm{NO}_{3}{ }^{-}>\mathrm{Cl}^{-}>\mathrm{SO}_{4}{ }^{2-}>\mathrm{CO}_{3}{ }^{2-}$ respectively. The negligible concentration of $\mathrm{CO}_{3}{ }^{2-}$ in most 284 of the water samples invariably portray the $\mathrm{HCO}_{3}{ }^{-}$as predominant weak acid. The dominance of $\mathrm{HCO}_{3}{ }^{-}$in 285 the water samples reflect extensive chemical weathering of silicate minerals rich in alkaline earths, in part, 
due to the high residence time of groundwater in the aquifers (e.g., Hem, 1989). The $\mathrm{HCO}_{3}{ }^{-}$was probably

287 formed within the soil zone during its passage to the groundwater region following the disintegration of

288 organic matter, which liberates $\mathrm{CO}_{2}$ that further reacts with groundwater in the soil (e.g., Talabi and Tijani,

289 2013). This reaction consequently produced weak carbonic acid $\left(\mathrm{H}_{2} \mathrm{CO}_{3}\right)$ which triggered the decomposition

290 of minerals in the rock. This reaction facilitated the dissolution and subsequent liberation of cations and

291 anions into the groundwater, which accounts for the wide range of hydrochemical characteristics (e.g., Talabi

292 and Tijani, 2013; Carmi et al., 2019).

\subsection{Chemical characteristics}

\subsubsection{Piper diagram}

Fig. 6a shows Piper trilinear diagram of the studied groundwater samples while their corresponding classification and interpretation is presented in Table 5. The samples plot within the field (IV), corresponding to $\mathrm{Ca}^{2+}-\mathrm{Mg}^{2+}-\mathrm{HCO}_{3}{ }^{-}$hydrochemical facies. This water type implies an exceedance of alkaline earth elements $\left(\mathrm{Ca}^{+}+\mathrm{Mg}^{+}\right)$over alkalis $\left(\mathrm{Na}^{+}+\mathrm{K}^{+}\right)$and dominance of weak acid $\left(\mathrm{CO}_{3}{ }^{2-}+\mathrm{HCO}_{3}{ }^{-}\right)$over strong acid $\left(\mathrm{SO}_{4}{ }^{2-}+\mathrm{Cl}^{-}+\mathrm{F}^{-}\right)$. The water type is consistent with field (A) (Fig. 6a), which is interpreted as normal earth alkaline associated with carbonates (See Table 5) (Langguth, 1966). The water depicts a fresh-brackish water of almost ancient and non-contemporary recharge, which ascends from deep-seated aquifers along major faults. This water type is probably attributed to rainfall recharge processes, with low $\mathrm{EC}$ content. The $\mathrm{Ca}^{2+}$ ion in the groundwater most likely originated through dissolution of precipitates (e.g., $\mathrm{CaCO}_{3}$ and $\mathrm{Ca}-\mathrm{Mg}$ $\left.\left(\mathrm{CO}_{3}\right)_{2}\right)$ during recharge. This implies that the studied groundwater consists of mixtures of various alkaline metals with a temporary hardness (Singh and Kumar, 2015). The samples are trending towards the bicarbonate and sulphate/chloride field (B) with three samples plotting within the boundary of fields (A) and (B) (Fig. 6a). This behaviour depicts a mild mixing of fresh and saline water, or probably fresh water that underwent evaporation (Panagopoulos et al., 2005) and affect only 10\% of the total groundwater in the area. Indeed, none of the groundwater samples plot within the zones (II) and (III), thus, preclude the presence of $\mathrm{Na}^{+}-\mathrm{K}^{+}-\mathrm{Cl}^{-}-\mathrm{SO}_{4}{ }^{2-}$ and $\mathrm{Na}^{+}-\mathrm{K}^{+}-\mathrm{HCO}_{3}{ }^{-}$water facies.

\subsubsection{Durov diagram}

The Durov diagram (Fig. 6b) and its corresponding water classification (Table 6) has been used to shed light on the important hydrochemical processes. The cationic triangle to the left shows clustering of water samples within the $\mathrm{Mg}^{2+}$ water type field, while few samples straddle the intermediate and $\mathrm{Ca}^{2+}$ water type 
316 the anionic triangle, with two samples plotting within the intermediate $\mathrm{Cl}^{-}$water type zone. The clustering

317 within the cationic $\left(\mathrm{Ca}^{2+}-\mathrm{Mg}^{2+}\right)$ and anionic $\left(\mathrm{HCO}_{3}^{-}\right)$triangles is consistent with the water type $\left(\mathrm{Ca}^{2+}-\mathrm{Mg}^{2+}\right.$

$318-\mathrm{HCO}_{3}$ ) extrapolated from the Piper trilinear diagram (Fig. 6a). In the Durov diagram, majority of the 319 samples plot in the ionic exchange field while some are unevenly distributed within the fields (1), (2) and 320 mixing or dissolution field (5) (Fig. 6b). This behaviour further confirm the possible low-level mixing 321 between the fresh and saline water end-members observed in the Piper diagram. Notably, the extensive 322 anionic and cationic exchange are most likely the major chemical processes that led to the mixing or 323 dissolution during groundwater flow and recharge (cf. Kumar et al., 2006).

\subsubsection{Bi-variant plots}

Table 7 shows the summary of computed ion-exchange process in the studied basement aquifer and the associated Gibbs ratio. The chloro-alkaline index (CA-I and CA-II) yielded positive values ( 0.0383 to 0.75

327 and 0.00248 to 0.08346 ). This implies that $\mathrm{Na}^{+}$and $\mathrm{K}^{+}$ions exchange is basically from the water with $\mathrm{Mg}^{2+}$ 328 and $\mathrm{Ca}^{2+}$ ions of the rock, consistent with a direct base-exchange reaction associated with soft water (Kumar et al., 2013). Gibbs (1970) introduced the diagram of cation $\left(\mathrm{Na}^{+} / \mathrm{Na}^{+}+\mathrm{Ca}^{2+}\right)$ versus TDS and anion $\left(\mathrm{Cl}^{-} / \mathrm{Cl}^{-}\right.$ $+\mathrm{HCO}^{-}$) versus TDS to demonstrate the natural processes controlling groundwater chemistry. These processes include dominance of rainfall, rock weathering (rock-water interaction), evaporation and precipitation. The groundwater samples plot in the field of rock dominance (Fig. 7a-b), indicating that weathering of minerals and base-exchange reaction are the major processes controlling the groundwater chemistry. However, the groundwater samples form a horizontal straight line in the plot of EC versus $\mathrm{Na}^{+} / \mathrm{Cl}^{-}$ (Fig. 7c), precluding a significant variation in $\mathrm{Na}^{+} / \mathrm{Cl}^{-}$ratio with increasing EC. This pattern indicates that

337 (Jankowski and Acworth, 1997).

\subsubsection{Scatter diagrams}

339 The $\mathrm{Na}^{+}-\mathrm{Cl}^{-}$relationship is often used to identify the major processes responsible for the marked 340 increase in the salinity of groundwater in arid/semi-arid regions. According to Meybeck (1987), if sodium is 341 sourced from halite dissolution, the ratio of $\mathrm{Na}^{+}-\mathrm{Cl}^{-}$will be approximately 1 . However, the sample points in 342 Fig. 8a deviated from the 1:1 relation line, indicating that halite dissolution is unlikely the major source of 
$343 \mathrm{Na}^{+}$in the studied groundwater. This lives open the possibility that the mild/low salinity may be due to silicate 344 weathering and ion exchange reaction. Moreover, the trend of $\mathrm{Cl}^{-}$versus $\mathrm{K}^{+} / \mathrm{Cl}^{-}$(Fig. $8 \mathrm{~b}$ ) displays $\mathrm{K}^{+} / \mathrm{Cl}^{-}$ 345 ratio $>0.2$, diagnostic of dissolution and weathering of silicate minerals (such as K-feldspar and plagioclase) 346 in the crystalline basement rocks (e.g., Chang and Wang, 2010) as buttressed by the reaction:

A hydrogeochemical system with ratio of $\left(\mathrm{HCO}_{3}{ }^{-}+\mathrm{SO}_{4}{ }^{2-}\right)$ versus $\left(\mathrm{Ca}^{2+} \mathrm{Mg}^{2+}\right)$ close to the relation line (1:1) implies chemical reaction mainly associated with dissolution of dolomite, calcite and gypsum (e.g., Su, 2009). The binary plot of $\left(\mathrm{HCO}_{3}{ }^{-}+\mathrm{SO}_{4}{ }^{2-}\right)$ versus $\left(\mathrm{Ca}^{2+} \mathrm{Mg}^{2+}\right)$ shows a larger percentage of the samples fall above the 1:1 line (Fig. 8c). This further indicates that dissolution/weathering of silicate and sulphate minerals

353 calcite, dolomite and gypsum dissolution. Further, the water samples display slight positive correlation in the 354 alkalinity versus $\mathrm{Mg}^{2+}$ diagram (Fig. 8d), with low correlation coefficient $(\mathrm{R}=0.35)$ between the variables. 355 Most of the sample points plot below the 1:1 equiline, implying that the excess alkalinity in the groundwater 356 must have been balanced by alkalies (e.g., Rao 2008; Ganyaglo, 2012). Evaporation in arid regions often 357 elevate $\mathrm{Cl}^{-}$contents in groundwater, and reflects the level of mineralization (e.g., Yang et al., 2016). The plot 358 of TDS versus $\mathrm{Cl}^{-}$display an increase in $\mathrm{Cl}^{-}$with increasing TDS (Fig. 8e), indicating the relative role of 359 evaporation process in the studied groundwater.

Another important organoleptic parameter reflecting the extent of salinity or mineralization is the electrical conductivity (EC). High concentration of EC implies groundwater with a long residence time (e.g., 362 Walraevens et al., 2018). Therefore, concentration of EC in the studied groundwater (127 to $337 \mu \mathrm{s} / \mathrm{cm})$ is reflective of the extent of aluminosilicate weathering and the roles of other secondary processes (e.g., 364 evaporative concentration, evaporate salts dissolution and anthropogenic pollution). A fairly positive 365 correlation is demonstrated between EC and other important ions such as $\mathrm{Ca}^{2+}(\mathrm{r}=0.65), \mathrm{Na}^{+}(\mathrm{r}=0.71), \mathrm{K}^{+}(\mathrm{r}$ $366=0.75), \mathrm{Cl}^{-}(\mathrm{r}=0.62)$ and $\mathrm{NO}_{3}^{-}(\mathrm{r}=0.60)($ Table 8$)$. These positive correlations imply an increase of these 367 elements with increasing EC, thus, a proper replicate of TDS (e.g., APHA-AWWAWEF, 2012). These 368 elements are products of rock-water interactions, particularly the weathering of silicate minerals. The strong 369 correlation between $\mathrm{EC}$ and $\mathrm{K}^{+}(\mathrm{r}=0.75)$ implies that the weathering of $\mathrm{K}$-feldspar and micas (which resulted 
370 in the liberation of $\mathrm{K}^{+}$) has also been influential in the mild salinity of the studied groundwater (cf. Petrides 371 et al., 2006).

372 The $\mathrm{Cl}^{-}-\mathrm{Ca}^{2+}$ ratio (in meq/l) is an important parameter controlling the hydrodynamics of groundwater 373 (Li et al., 2011). In a low mineralized setting, $\mathrm{Ca}^{2+}$ is usually the dominant cation. Progressive increase in 374 TDS can lead to an increase in $\mathrm{Mg}^{2+}$, and further increase in TDS can make $\mathrm{Na}^{+}$to become the dominant 375 cation in the hydrochemical system. High TDS in groundwater can hinder the migration of $\mathrm{Cl}^{-}$, leading to a 376 marked increase in $\mathrm{Cl}^{-}$with increasing TDS (Fig. 8e). Consequently, the $\mathrm{Cl}^{-} / \mathrm{Ca}^{2+}$ ratios progressively increase 377 with increasing TDS (Fig. 8f), reflective of an extensive hydrodynamic worsening (Li et al., 2011). Based on 378 the plot of TDS versus $\mathrm{Cl}^{-} / \mathrm{Ca}^{2+}$ (Fig. 8f), there is a marked hydrodynamic heterogeneity in the studied 379 groundwater which is believed to be controlled by extensive weathering of the parent rock (Dewandel et al., 2006, 2012; Tziritis et al., 2017). During this process, the minerals in the rock experienced biogeochemical 381 hydrolysis weathering (i.e., reaction between hydrogen ion and silicate minerals such as feldspars) which 382 consequently transform them into clay-rich materials (Nahon, 1991). The abundance of feldspars in the rock, coupled with the widespread alluvial deposits consisting of clay, sand, silt, river bed sand and gravel (See Figs. 2 \& 4) invariably attest to aforementioned process in the study area.

According to $\mathrm{Li}$ et al. (2013), the ratio of $\mathrm{Na}^{+}$and $\mathrm{Cl}^{-}$(in mmol/l) is supposed to be 1 if these ions are derived mainly from halite dissolution. However, almost all the groundwater samples plot strictly below the 1:1 relation line (Fig. 9a), indicating higher $\mathrm{Cl}^{-}$relative to $\mathrm{Na}^{+}$and precluding halite dissolution as the major source of these ions. Thus, it is probable that other reactions (e.g., water-rock interaction and anthropogenic activities) may have influenced their concentrations. Notably, $\mathrm{Na}^{+}$deficiency in the hydrogeochemical system is buttressed by cation exchange (equations 10 and 11). This process probably enhanced the absorption of $\mathrm{Na}^{+}$into the aquifer which consequently decreases the $\mathrm{Na}^{+}$ion in the groundwater thereby making most of the samples to plot below the 1:1 relation line (Fig. 9a).

$$
2 \mathrm{Na}^{+}+\mathrm{CaX}_{2}=\mathrm{Ca}^{2+}+2 \mathrm{NaX}
$$

$$
2 \mathrm{Na}^{+}+\mathrm{MgX}_{2}=\mathrm{Mg}^{2+}+2 \mathrm{NaX}
$$

The $\mathrm{Na}^{+} / \mathrm{Cl}^{-}$ratio $<1: 1$ is associated with animal excrement and domestic sewage which infiltrate into the shallow weathered aquifer and increases the $\mathrm{Cl}^{-}$content in the groundwater (cf. Li et al., 2014). The plot 

domestic and animal sewage.

\subsubsection{Multivariate statistical techniques}

401 Analysis of the principal components of the studied groundwater has been carried out to identify the significant factors (with eigenvalue $>1$ ) controlling the groundwater chemistry. The analysis revealed three factors characterized by cumulative percentage variance of $76.70 \%$ and progressively decreasing eigenvalues and percentage variances from factor 1 to factor 3 (Table 9). The three factors yielded a cumulative percentage variance of $76.70 \%$. Factor 1, with eigen value of 5.50 accounts for $45.80 \%$ of the total variance characterized by strong positive loading $(<0.75)$ with respect to $\mathrm{Ca}^{+}, \mathrm{Na}^{+}, \mathrm{Cl}^{-}, \mathrm{NO}_{3}{ }^{-}, \mathrm{EC}$ and TDS. Calcium

$407\left(\mathrm{Ca}^{+}\right)$display high loading of 0.74 which may be ascribed to its liberation as by-product of 408 weathering/dissolution of silicate minerals (e.g., amphiboles, feldspars, and pyroxenes), while high loadings of $\mathrm{Na}^{+}$and $\mathrm{Cl}^{-}(0.884$ and 0.774$)$ is likely attributable to natural (mild) salinity, a process that is also 410 corroborated by the high positive correlation between $\mathrm{Na}^{+}$and $\mathrm{Cl}^{-}(\mathrm{r}=0.703$, See Table 8$)$. The high loading 411 of $\mathrm{Na}^{+}$may also be related to weathering of feldspar or cation exchange, while that of $\mathrm{Cl}^{-}$may be associated 412 with anthropogenic activities (Singh et al., 2005; Huang et al., 2013). Similarly, the strong positive loading 413 portrayed by $\mathrm{NO}_{3}^{-}(0.901)$ and TDS (0.718) may be due to anthropogenic activities such as runoff from 414 animal waste (manure) and fertilizer lawns as well as failure of on-site septic systems (Wang et al., 2020). 415 High loading of EC (0.715) is probably attributable to rapid evaporation, which increases the natural salinity 416 of the water as seen from the strong positive loading of $\mathrm{Na}^{+}$. Therefore, factor 1 can be interpreted as rock417 water interaction during silicate weathering, natural salinity and anthropogenic activities.

418 Factor 2 shows lower eigenvalue (2.50) and \%variance (20.79) as compared with factor 1 (5.50 and 419 45.80). This factor yielded high loadings with respect to $\mathrm{Mg}^{2+}, \mathrm{Cl}^{-}$, $\mathrm{TH}$ and $\mathrm{pH}$ (Table 9). Strong positive 420 loading displayed by $\mathrm{Mg}^{2+}$ (0.874) likely reflects weathering of mafic minerals (e.g., biotite), while that of $421 \mathrm{pH}(0.777)$ may be attributable to the precipitation-dissolution of $\mathrm{Ca}^{2+}$ and $\mathrm{Mg}^{2+}$, a process that probably 422 enhanced the mild salinity of the groundwater. Further, strong positive loading with respect to TH (0.886) 423 is largely controlled by the availability of the major ions $\left(\mathrm{Ca}^{2+}\right.$ and $\left.\mathrm{Mg}^{2+}\right)$, as corroborated by the strong 424 positive correlation of $\mathrm{TH}$ with $\mathrm{Mg}(\mathrm{r}=0.801)$ (Table 8$)$. Thus, this factor can be interpreted as natural 425 hardness and rock-water interaction (weathering). 
Factor 3, with eigen value and \%variance of 1.22 and $10.14 \%$, respectively is the least significant

427 contributor of groundwater chemistry. This factor is characterized by a high fluoride loading of 0.851 ,

428 attributable to fluoride-containing pesticides and fluorinated pharmaceuticals, hence, can also be interpreted

429 as anthropogenic activities. The strong positive correlation of TDS and EC with the main cations and anions

430 (See Table 8), coupled with the high loadings of TDS, EC and $\mathrm{K}^{+}$(Table 9) reflect their significant

431 contribution to the overall mineralization in studied groundwater. This shows that the ions in the basement

432 aquifers originated from geogenic source during weathering and dissolution or precipitation (Saxena and

433 Ahmed, 2003; Sahu et al., 2021).

434 Dendrogram of hydrogeochemical data generated from the hierarchical cluster analysis (HCA) indicates

435 two clusters (Fig. 10). Cluster 1 is further divided into two separate sub-clusters. The sub-cluster 1 comprised

436 of EC, TDS, $\mathrm{K}^{+}$with $\mathrm{Ca}^{2+}$ loosely bound to it. This cluster can be interpreted as anthropogenic activities

437 probably controlled by $\mathrm{K}^{+}$as well as rock-water interaction (silicate weathering) and natural salinity

438 associated with dissolution of $\mathrm{Ca}^{2+}$, which can cause a mild hardness in the groundwater. This agrees well

439 with factor 1 in the principal component analysis. The second sub-cluster indicate similarities between $\mathrm{Na}^{+}$,

$440 \mathrm{NO}_{3}{ }^{-}$, and $\mathrm{Cl}^{-}$with loosely attached $\mathrm{F}^{-}$. As the cluster comprised of $\mathrm{Na}^{+}$and $\mathrm{Cl}^{-}$, it can be described as natural

441 salinity, in line with factor 1 in PCA. By virtue of $\mathrm{NO}_{3}{ }^{-}$and $\mathrm{F}^{-}$, it can also be interpreted as anthropogenic

442 activities, which is consistent with factor 1 and 3 in the PCA. Cluster 2 consist of $\mathrm{Mg}^{2+}, \mathrm{TH}, \mathrm{pH}$ with $\mathrm{HCO}_{3}{ }^{-}$

443 loosely bound to it. This cluster can be interpreted as temporary hardness and precipitation, which can cause

444 residual bicarbonate hazard (e.g., Kumar et al., 2016). This cluster is consistent with factor 2 in the PCA.

\subsection{Groundwater quality assessment}

446 The pollution index of groundwater (PIG) examines the relative contributions of the major 447 physicochemical parameters from each water sample. Subba Rao (2012) proposed that water quality 448 parameter with an overall water quality (Ow) greater than 0.1 (i.e., 10\% of the PIG value of 1.0) has the 449 greatest influence on the pollution state of the groundwater. In the present study, the $\mathrm{pH}$ of $70 \%$ of the 450 groundwater samples (i.e. 21 out of the 30 samples) yielded Ow values greater than 0.1 ( 0.11 to 0.16 , average $451=0.12)$ while $\mathrm{NO}_{3}{ }^{2-}$ of $23.3 \%$ of the water samples also yielded $\mathrm{Ow}$ values greater than 0.1 (0.11 to 0.24 , 452 average $=0.17)($ Table 10$)$. These elevated values indicate that $\mathrm{pH}$ and $\mathrm{NO}_{3}{ }^{2-}$ have the highest impact on the

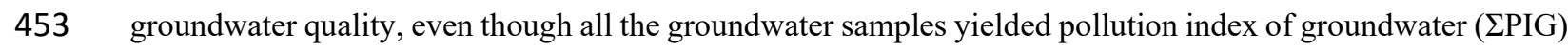
454 less than 1 ( 0.27 to 0.737 ) (Table 10$)$, indicating an insignificant pollution based on the standard rating of 
455 Subba Rao (2012). The elevated Ow of pH in most of the samples may be as a result of the precipitation456 dissolution of $\mathrm{Ca}^{2+}$ and $\mathrm{Mg}^{2+}$ which invoked natural salinity of the water. The high $\mathrm{Ow}$ of $\mathrm{NO}_{3}{ }^{2-}$ in some of 457 the groundwater samples may be attributable to the use fertilizer (e.g., NPK) and animal manure on farm 458 lands, the pollution effect of which is insignificant given the low PIG $(<0.1)$ of the all the studied groundwater 459 samples.

460 Despite the artisanal mining of monazite in the area, the pollution index of groundwater is within the 461 permissible limits for drinking. This may be due to the current shallow depth of the mine pits (average of 3.2 462 meters) which is lower than the minimum depth of weathered regolith and collapse zone (6.3 meters) within 463 the vicinity of the mine pits. Besides, field investigation have shown that the mine pits are sited at areas of 464 low topographic heights with appreciable distance from the boreholes where water samples for this study 465 were collected.

\section{5. Conclusion}

467 Hydrogeochemistry and quality assessment of borehole groundwater within the basement aquifers in 468 Mubi South area, north-eastern Nigeria has been thoroughly monitored and examined. The cations-anions 469 contents range from $\mathrm{Ca}^{2+}>\mathrm{Mg}^{2+}>\mathrm{K}^{+}>\mathrm{Na}^{+}$and $\mathrm{HCO}_{3}{ }^{-}>\mathrm{NO}_{3}{ }^{-}>\mathrm{Cl}^{-}>\mathrm{SO}_{4}{ }^{2-}$ respectively. Deductions from 470 various hydrochemical systematics such as Piper, Gibbs and Durov diagrams as well as chloro-alkaline 471 indices and statistical techniques indicate silicate weathering as the primary process controlling the 472 hydrogeochemistry of groundwater in the area. However, other hydrochemical processes such as 473 anthropogenic activities and evaporative concentration and anthropogenic activities (such as fertilizer 474 application) also play a secondary role in the hydrochemical evolution of the groundwater. Estimation based 475 on the pollution index of groundwater (PIG) indicate an insignificant pollution state of less than $1(0.27-$ 476 0.737) for the groundwater samples collected from all the 30 boreholes in the study area.

\section{Acknowledgement}

478 We thank Mr. Ephraim Ibrahim for the assistance during the geologic field mapping and groundwater 479 sampling. The first author is a beneficiary of the fully funded Chinese Government Scholarship, a gesture he 480 wishes to acknowledge. 


\section{Declarations}

483 This research received no specific grant from any funding agency in the public, commercial, or not-for-profit

484 sectors. We know no conflict of interest associated with this publication, and there has been no significant

485 financial support for this work that could have influenced its outcome. All generated or analyzed data during

486 this study are included in this submission as Tables. We declare that this manuscript is original, has not been

487 published before and is not currently being considered for publication elsewhere. Free version of softwares

488 used for data analysis such as AQqa, SPSS, and CorelDraw Graphics Suit are available online.

489

490

491

492

493

494

495

496

497

498

499

500

501

502

503

504 
506 Adebayo AA, Tukur AL (1999) Adamawa State in maps - Paraclette Publishers, Yola, 112 p.

507 Adimalla N, Qian H, Nandan MJ (2020) Groundwater chemistry integrating the pollution index of groundwater and evaluation of potential human health risk: A case study from hard rock terrain of south India. Ecotoxicol Environ Saf 206:111217. https://doi.org/10.1016/j.ecoenv.2020.111217.

Akiwumi FA (1997) The need for more widespread use of geological criteria in water quality assessment in Africa. Freshwater Contamination, Proceedings of Rabat Symposium S4, IAHS publication, 243:359365.

Anand RR, Paine M (2002) Regolith geology of the Yilgarn Craton, Western Australia: implications for exploration. Aust J Earth Sci 49(1):3-162. https://doi.org/10.1046/j.1440-0952.2002.00912.x.

APHA (2012) Standard methods for the examination of water and wastewater. In: Clesceri, A., Lenrore, Green berg, Anorld, Eaton (Eds.), twentieth ed.

Avdullahi S., Fejza I, Tmava A (2013) Evaluation of groundwater pollution using multivariate statistical analysis: A case study from Burimi area, Kosovo. J Bio \& Env Sci 3(1):95-102.

Banks EW, Simmons CT, Love AJ, Cranswick R, Werner AD, Bestland EA, Wood M, Wilson T (2009) Fractured bedrock and saprolite hydrogeologic controls on groundwater/surface-water interaction: a conceptual model (Australia). Hydrogeol J 17(8):1969-1989. https://doi.org/10.1007/s10040-009$\underline{0490-7 .}$

Boutt DF, Diggins P, Mabee S (2010) A field study (Massachusetts, USA) of the factors controlling the depth of groundwater flow systems in crystalline fractured-rock terrain. Hydrogeol J 18(8):1839-1854. https://doi.org/10.1007/s10040-010-0640-y.

Carmi I, Kronfeld J, Moinester M (2019) Sequestration of atmospheric carbon dioxide as inorganic carbon in the unsaturated zone under semi-arid forests. Catena 173:93-98. https://doi.org/10.1016/j.catena.2018.09.042.

Chang J, Wang G (2010) Major ions chemistry of groundwater in the arid region of Zhangye Basin, northwestern China. Environ. Earth Sci J 61(3):539-548. https://doi.org/10.1007/s12665-009-0364-2.

Chaturvedi A, Bhattacharjee S, Mondal GC, Kumar V, Singh PK, Singh AK (2019) Exploring new correlation between hazard index and heavy metal pollution index in groundwater. Ecol Indic 97:239246. https://doi.org/10.1016/j.ecolind.2018.10.023. 
Chen J, Wu H, Qian H, Gao Y (2017) Assessing nitrate and fluoride contaminants in drinking water and their health risk of rural residents living in a semiarid region of northwest China. Expo Health 9(3):183-195. https://doi.org/10.1007/s12403-016-0231-9.

Chilton PJ, Foster S (1995) Hydrogeological Characterisation and Water-Supply Potentiel of Basement Aquifers in Tropical Africa. Hydrogeol J 3:36-49. https://doi.org/10.1007/s100400050061.

Chimphamba J, Ngongondo C, Mleta P (2009). Groundwater chemistry of basement aquifers: A case study of Malawi. In: Titus, R.; Beekman, H., Adams, S. \& Strachan (eds). The Basement Aquifers of Southern Africa. Report to the Water Research Commission, 39-44.

Consulint International S.R.L. and Consulint Nigerian Limited (1976) Water Surveys of the Northeastern State, Hydrogeological Map, Mubi Sheet 38, Scale: 1:250, 000.

Dewandel B, Lachassagne P, Wyns R, Maréchal JC, Krishnamurthy NS (2006) A generalized 3-D geological and hydrogeological conceptual model of granite aquifers controlled by single or multiphase weathering. J Hydrol 330(1-2):260-284. https://doi.org/10.1016/j.jhydrol.2006.03.026.

Dewandel B, Maréchal JC, Bour O, Ladouche B, Ahmed S, Chandra S, Pauwels H (2012) Upscaling and regionalizing hydraulic conductivity and effective porosity at watershed scale in deeply weathered crystalline aquifers. J Hydrol 416:83-97. https://doi.org/10.1016/j.jhydrol.2011.11.038.

Doumas P, Munoz M, Banni M, Becerra S, Bruneel O, Casiot C, Cleyet-Marel JC, Gardon J, Noack Y, Sappin-Didier V (2018) Polymetallic pollution from abandoned mines in Mediterranean regions: a multidisciplinary approach to environmental risks. Reg Environ Change 18(3):677-692. https://doi.org/10.1007/s10113-016-0939-x.

du Plessis A (2019) Primary Water Quality Challenges, Contaminants and the World's Dirtiest Places. In Water as an inescapable risk. 79-114. https://doi.org/10.1007/978-3-030-03186-2_5.

Durov SA (1948) Natural Waters and Graphic Representation of Their Composition. Doklady Akademii Nauk SSSR, 59, 87-90.

Eaton FM (1950) Significance of carbonates in irrigation waters. Soil Sci 69:123-133. https://doi.org/10.1097/00010694-195002000-00004.

Egbueri JC (2020) Groundwater quality assessment using pollution index of groundwater (PIG), ecological risk index (ERI) and hierarchical cluster analysis (HCA): a case study. Groundw Sustain Dev 10:100292. https://doi.org/10.1016/j.gsd.2019.100292. 
Elumalai V, Brindha K, Lakshmanan E (2017) Human exposure risk assessment due to heavy metals in

564 groundwater by pollution index and multivariate statistical methods: a case study from South Africa.

$565 \quad$ Water 9(4):234. https://doi.org/10.3390/w9040234.

566 Evans CD, Davies TD, Wigington PJ, Tranter M, Kretser WA (1996) Use of factor analysis to investigate processes controlling the chemical composition of four streams in Adirondack Mountains, New York. J Hydrol 185:297-316. https://doi.org/10.1016/0022-1694(95)02997-4.

Ferré EC, Deleris J, Bouchez JL, Lar AU, Peucat JJ (1996) The Pan-African reactivation of Eburnean and Archaean provinces in Nigeria: structural and isotopic data. J Geol Soc London 153:719-728. https://doi.org/10.1144/gsjgs.153.5.0719.

Field, A (2000) Discovering Statistics using SPSS for Windows. London - Thousand Oaks - New Delhi: Sage publications.

Fisher RS, Mulican W (1997) Hydrochemical evolution of sodium-sulphate and sodium-chloride

Freeze RA, Cherry JA (1979). Groundwater. Prentice-Hall Inc., Englewood Cliffs, Vol. 7632, 604 pp.

578 Foster SSD, Chilton PJ (2003) Groundwater: the processes and global significance of aquifer degradation.

579 Philosophical Transactions of the Royal Society of London. Series B: Biological Sciences, $580 \quad 358(1440): 1957-1972$. https://doi.org/10.1098/rstb.2003.1380.

581 Foster S, Chilton J, Nijsten GJ, Richts A (2013) Groundwater-a global focus on the 'local resource'. Curr Opin Env Sust 5(6):685-695. https://doi.org/10.1016/j.cosust.2013.10.010.

583 Ganyaglo SY (2012) Preliminary groundwater quality assessment in the central region of Ghana. Environ Earth Sci 66:573-587. https://doi.org/10.1007/s12665-011-1266-7.

Gibbs (1970) Mechanisms Controlling World Water Chemistry. J Sci 170(3962):1088-1090. https://doi.org/10.1126/science.170.3962.1088.

587 Guidelines for Canadian Drinking Water Quality (GCDWQ) (2007) Portable water-recommended limits, ED 031-02 3pp.

Guihéneuf N, Boisson A, Bour O, Dewandel B, Perrin J, Dausse A, Viossanges M, Chandra S, Ahmed S, 590 Maréchal JC (2014). Groundwater flows in weathered crystalline rocks: Impact of piezometric 
variations and depth-dependent fracture connectivity. J Hydrol 511:320-334. https://doi.org/10.1016/j.jhydrol.2014.01.061.

593 Health Canada (2012) Guidelines for Canadian drinking water quality supporting documents. [Online] http://www.hc-sc.gc.ca/ewh-semt/pubs/water-eau/doc_sup appui/index_e.html. Accessed 16 February, 2021.

Hem JD (1989) Study and Interpretation of the Chemical Characteristics of Natural Water. Water Supply Paper 2254. 3rd edition. US Geological Survey, Washington DC. 263p.

Holland M (2011) Hydrogeological characterisation of crystalline basement aquifers within the Limpopo Province, South Africa (Doctoral dissertation, University of Pretoria).

Horten RK (1965) An Index number for rating water quality. J Water Poll Cont Fed 37(3):300-306.

Huang G, Sun J, Zhang Y, Chen Z, Liu F (2013) Impact of anthropogenic and natural processes on the evolution of groundwater chemistry in a rapidly urbanized coastal area, South China. Sci Total Environ 463: 209-221. https://doi.org/10.1016/j.scitotenv.2013.05.078.

Jankowski J, Acworth RI (1997) Impact of debris-flow deposits on hydrogeochemical processes and the development of dryland salinity in the Yass River catchment, New South Wales, Australia. Hydrogeol J 5:71-88. https://doi.org/10.1007/s100400050119.

Jones MJ (1985) The weathered zone aquifers of the basement complex areas of Africa. Q J Eng Geol Hydrogeol 18(1):35-46. https://doi.org/10.1144/gsl.qjeg.1985.018.01.06.

Kaiser H (1974) An index of factorial simplicity. Psychometrika, 39:31-6. https://doi.org/10.1007/BF02291575.

Key RM, Johnson CC, Horstwood MSA, Lapworth DJ, Knights KV, Kemp SJ, Watts MJ, Gillespie M, Adekanmi MA, Arisekola TM (2012) Investigating high zircon concentrations in the fine fraction of stream sediments draining the Pan-African Dahomeyan Terrane in Nigeria. Appl Geochem 27:15251539. https://doi.org/10.1016/j.apgeochem.2012.04.009.

Kulinkina AV, Plummer JD, Chui KK, Kosinski KC, Adomako-Adjei T, Egorov AI, Naumova EN (2017) Physicochemical parameters affecting the perception of borehole water quality in Ghana. Int J Hyg Environ Health 220(6):990-997. https://doi.org/10.1016/j.ijheh.2017.05.008. 
618

619

620

621

622

623

624

625

626

627

628

629

630

631

Kumar M, Ramanathan AL, Rao MS, Kumar B (2006) Identification and evaluation of hydrogeochemical processes in the groundwater environment of Delhi, India. Environ Geol 50(7):1025-1039. https://doi.org/10.1007/s00254-006-0275-4.

Kumar SK, Bharani R, Magesh NS, Godson PS, Chandrasekar N (2013) Hydrogeochemistry and groundwater quality appraisal of part of south Chennai coastal aquifers, Tamil Nadu, India using WQI and fuzzy logic method. Appl Water Sci 4(4):341-350. https://doi.org/10.1007/s13201-013-0148-4.

Kumar SK, Logeshkumaran A, Magesh, Godson, NS, Chandrasekar N (2015) Hydrogeochemistry and application of water quality index (WQI) for groundwater quality assessment, Ann Nagar, part of Chennai City, Tamil Nadu, India. Appl Water Sci 5:335-343. https://doi.org/10.1007/s13201-014$\underline{0196-4 .}$

Kumar VS, Sharma A, Bhardwaj R, Thukral AK (2016) Monitoring and characterization of soils from River Bed of Beas, India, using Multivariate and remote sensing techniques. Br J Appl Sci Technol 12(2):112. https://doi.org/10.9734/BJAST/2016/21611.

Langguth HR (1966) Groundwater verhaltisse in Bereiech Des Velberter. Sattles. Der Minister Fur Eraehrung, Land Wirtsch Forste (pp. 127). Duesseldorf: NRW.

Li PY, Qian H, Wu JH (2011) Hydrochemical Characteristics and Evolution Laws of Drinking Groundwater in Pengyang County, Ningxia, Northwest China. E-J Chem 8(2):565-575. https://doi.org/10.1155/2011/472085.

Li PY, Qian H, Wu J. H., Zhang, Y. Q., \& Zhang, H. B., 2013. Major Ion Chemistry of Shallow Groundwater in the Dongsheng Coalfield, Ordos Basin, China. Mine Water Environ. 32, 195-206. https://doi.org/10.1007/s10230-013-0234-8.

Li P, Wu J, Qian H (2014) Hydrogeochemistry and Quality Assessment of Shallow Groundwater in the Southern Part of the Yellow River Alluvial Plain (Zhongwei Section), Northwest China. Earth Sci Res J 18(1):27-38. https://doi.org/10.15446/esrj.v18n1.34048.

Lloyd JA, Heathcote JA (1985) Natural inorganic hydrochemistry in relation to groundwater: An introduction. Oxford Uni. Press, New York 296 pp.

Lu KL, Liu C, Jang CS (2011) Using multivariate statistical methods to assess the groundwater quality in an arsenic-contaminated area of Southwestern Taiwan. Environ. Monit. Assess. 184:6071-6085. https://doi.org/10.1007/s10661-011-2406-y. 

3(3):403-414. https://doi.org/10.1016/0967-0661(95)00014-1.

649 Meybeck M (1987) Global chemical weathering of surficial rocks estimated from river dissolved loads. Am J Sci J 287(5):401-428. https://doi.org/10.2475/ajs.287.5.401.

651 Mohapatra PK, Vijay R, Pujari PR, Sundaray SK, Mohanty BP (2011) Determination of processes affecting 652 groundwater quality in the coastal aquifer beneath Puri City, India: a multivariate statistical approach. 653 Water Sci Technol 64(4):809-817. https://doi.org/10.2166/wst.2011.605.

654 Monged MH, Hassan HB, El-Sayed SA (2020) Spatial Distribution and Ecological Risk Assessment of 655 Natural Radionuclides and Trace Elements in Agricultural Soil of Northeastern Nile Valley, Egypt. Water Air Soil Pollut 231(7):1-24. https://doi.org/10.1007/s11270-020-04678-9.

Mapoma HWT, Xie X, Zhang L (2014) Redox control on trace element geochemistry and provenance of groundwater in fractured basement of Blantyre, Malawi. J Afr Earth Sci 100:335-345. https://doi.org/10.1016/j.jafrearsci.2014.07.010.

Mapoma HW, Xie X, Nyirenda MT, Zhang L, Kaonga CC, Mbewe R (2017) Trace elements geochemistry of fractured basement aquifer in southern Malawi: A case of Blantyre rural. J Afr Earth Sci 131:43-52. https://doi.org/10.1016/j.jafrearsci.2017.04.011.

Mary IA, Ramkumar T, Venkatramanan S (2011) Application of Statistical Analysis for the

Nahon DB (1991) Introduction to the Petrology of Soils and Chemical Weathering. Ed. Wiley. ISBN: 9780-471-50861-8. 336p.

Ngako V, Njonfang E, Aka FT, Affaton P, Nnange JM (2006) The North-South Paleozoic to Quaternary trend of alkaline magmatism from Niger-Nigeria to Cameroon: Complex interaction between hotspots and Precambrian faults J Afr Earth Sci 45:241-256. https://doi.org/10.1016/j.jafrearsci.2006.03.003.

673 Oyedele AA, Ayodele OS, Olabode OF (2019) Groundwater quality assessment and characterization of 674 shallow basement aquifers in parts of Sdo Ekiti metropolis, Southwestern Nigeria. SN Appl Sci 1:669. 675 https://doi.org/10.1007/s42452-019-0683-1. 
Panagopoulos GP, Lambrakis NJ, Katagas C, Papoulis D, Tsolis-Katagas P (2005) Water-rock interaction induced by contaminated groundwater in a karst aquifer, Greece. Environ Geol 49:300-313. https://doi.org/10.1007/s00254-005-0090-3.

Petrides B, Cartwright, I., Weaver TR (2006) The evolution of groundwater in the Tyrrell catchment, southcentral Murray Basin, Victoria, Australia, Hydrogeol J 14:1522-1543, https://doi.org/10.1007/s10040006-0057-9.

Pietersen K (2009) Aspects of groundwater management that is pertinent to basement aquifers in the southern African development community (SADC). The Basement Aquifers of Southern Africa, 148.

Piper AM (1944) A Graphic Procedure in the Geochemical Interpretation of Water-Analyses. Eos, Trans. Am. Geophys Union 25:914-928. http://dx.doi.org/10.1029/TR025i006p00914.

Rajankar PN, Gulhane, SR, Tambekar, DH, Ramteke DS, Wate SR (2009) Water quality assessment of groundwater resources in Nagpur Region (India) based on WQI. E-J Chem 6(3):905-908. https://doi.org/10.1155/2009/971242.

Rao SN (2008) Factors controlling the salinity in groundwater in parts of Guntur district, Andhra Pradesh, India. Environ Monit Assess J 138:327-341. https://doi.org/10.1007/s10661-007-9801-4.

Rao NS, Chaudhary M (2019) Hydrogeochemical processes regulating the spatial distribution of groundwater contamination, using pollution index of groundwater (PIG) and hierarchical cluster analysis (HCA): a case study. Groundw Sustain Dev 9:100238. https://doi.org/10.1016/j.gsd.2019.100238.

Reuschel M, Melezhik VA, Whitehouse MJ, Lepland A, Fallick AE, Strauss H (2012) Isotopic evidence for a sizeable seawater sulfate reservoir at 2.1 Ga. Precambrian Res 192:78-88. https://doi.org/10.1016/j.precamres.2011.10.013.

Romic M, Romic D (2003) Heavy metals distribution in agricultural topsoils in urban area. Environ Geol 43(7):795-805. https://doi.org/10.1007/s00254-002-0694-9.

Sahu S, Gogoi U, Nayak NC (2021) Groundwater solute chemistry, hydrogeochemical processes and fluoride contamination in phreatic aquifer of Odisha, India. Geosci Front 12(3):101093. https://doi.org/10.1016/j.gsf.2020.10.001.

Sawyer CN, McCarty PL (1978) Chemistry for Environmental Engineering (3rd ed.). New York: McGrawHill Book Co. 
Schoeller H (1967) Qualitative Evaluation of Ground Water Resources. In: Schoeller, H., Ed., Methods and Techniques of Groundwater Investigation and Development, Water Resource Series No. 33, UNESCO, Paris, 44-52.

Singh AK, Mondal GC, Singh, PK, Singh S, Singh TB, Tewary BK (2005) Hydrochemistry of reservoirs of Damodar River basin, India: weathering processes and water quality assessment. Environ Geol 48(8):1014-1028. https://doi.org/10.1007/s00254-005-1302-6.

Singh AK, Raj B, Tiwari AK, Mahato MK (2013) Evaluation of hydrogeochemical processes and groundwater quality in the Jhansi district of Bundelkhand region, India. Environ. Earth Sci. 70(3):12251247.

Stober I, Bucher K (2015) Hydraulic conductivity of fractured upper crust: insights from hydraulic tests in boreholes and fluid-rock interaction in crystalline basement rocks. Geofluids 15(1-2):161-178.

Subyani AM, Alahmadi ME (2010) Multivariate Statistical Analysis of Groundwater Quality in Wadi Ranyah, Saudi Arabia. JAKU; Earth Sci 21:29-46. https://doi.org/10.4197/ear.21-2.2.

Su YM (2009) A study of shallow groundwater quality distribution in the Ordos Cretaceous Artisan Basin based on GIS. Hydrogeol Eng Geol J 36 (1):24-29.

Talabi AO, Tijani MN (2013) Hydrochemical and stable isotopic characterization of shallow groundwater system in the crystalline basement terrain of Ekiti area, southwestern Nigeria. Appl Water Sci 3:229245. https://doi.org/10.1007/s13201-013-0076-3.

Tarits, C., Aquilina, L., Ayraud, V., Pauwels, H., Davy, P., Touchard, F., Bour, O., 2006. Oxido-reduction sequence related to flux variations of groundwater from a fractured basement aquifer (Ploemeur area, France). Appl Geochem 21(1):29-47. https://doi.org/10.1016/j.apgeochem.2005.09.004.

Todd DK (2001) Groundwater hydrology. Wiley, Canada 280-281.

Tziritis EP, Datta PS, Barzegar R (2017) Characterization and assessment of groundwater resources in a complex hydrological basin of central Greece (Kopaida basin) with the joint use of hydrogeochemical analysis, multivariate statistics and stable isotopes. Aquat Geochem 23(4):271-298. https://doi.org/10.1007/s10498-017-9322-x.

Wang Y, Peng J, Cao X, Xu Y, Yu H, Duan G, Qu J (2020) Isotopic and chemical evidence for nitrate sources and transformation processes in a plateau lake basin in Southwest China. Sci. Total Environ. 711, 134856. https://doi.org/10.1016/j.scitotenv.2019.134856. 
733 Walraevens K, Mjemah IC, Mtoni Y, Van Camp M (2015) Sources of salinity and urban pollution in the 734 Quaternary sand aquifers of Dar es Salaam, Tanzania. J Afr Earth Sci 102:149-165. 735 https://doi.org/10.1016/i.jafrearsci.2014.11.003.

736 Walraevens K, Bakundukize C, Mtoni YE, Van Camp M (2018) Understanding the hydrogeochemical 737 evolution of groundwater in Precambrian basement aquifers: A case study of Bugesera region in 738 Burundi. J Geochem Explor 188:24-42. https://doi.org/10.1016/j.gexplo.2018.01.003.

739 Williams AJ, Crossey LJ, Karlstrom KE, Newell D, Person M, Woolsey E (2013) Hydrogeochemistry of the 740 Middle Rio Grande aquifer system — Fluid mixing and salinization of the Rio Grande due to fault inputs. Chem Geol 351:281-298. https://doi.org/10.1016/j.chemgeo.2013.05.029.

World Health Organization (WHO) (2017) Guidelines for drinking-water quality: fourth edition incorporating the first addendum. Geneva, License: CC BY-NC-SA 3.0 IGO. ISBN 978-92-4-154995-

Yang Q, Li Z, Ma H, Wang L, Martín JD (2016) Identification of the hydrogeochemical processes and assessment of groundwater quality using classic integrated geochemical methods in the Southeastern part of Ordos basin, China. Environ Pollut 218:879-888. 
761 Fig. 1. Regional geological map of Nigeria (after Ferré et al., 1996 and Key et al., 2012). Distribution of 762 rocks within the Cameroon volcanic line (after Ngako et al., 2006).

763 Fig. 2. Geological map of the study area.

764 Fig. 3. Annual rainfall pattern of the study area (after Adebayo and Tukur, 1999).

765 Fig. 4. Hydrogeological map of the study area and environs showing the location of boreholes (after 766 Consulint International s.r.1 and Consulint Nigeria, 1976).

767 Fig. 5. (a) Schematic weathered profile above crystalline basement rocks (after Wright, 1992), (b) Schematic 768 basement aquifer catenary cross section (after Wright, 1992).

769 Fig. 6. (a) Piper Trilinear diagram classifying major hydrochemical facies. Divisions in quadrilateral and 770 triangles (after Langguth, 1966), (b) Durov plot depicting hydrochemical processes. Division in the square 771 and two triangles are after Lloyd and Heathcoat (1985) and Singh and Kumar (2015).

772 Fig. 7. Gibb's Diagram (a) cation versus TDS, (b) anion versus TDS showing the overriding control of rock 773 dominance (silicate weathering) in the hydrogeochemical system of the area (after Gibbs, 1970), (c) $\mathrm{Na}^{+} / \mathrm{Cl}^{-}$ 774 vs. EC binary plot to interpret the evaporation/evapotranspiration (after Sahu et al., 2021).

775 Fig. 8. Scatter plots of cations and anions (a) $\mathrm{Cl}^{-}$versus $\mathrm{Na}^{+}$(meq/l), (b) $\mathrm{Cl}^{-}$versus $\mathrm{K}^{-} / \mathrm{Cl}^{-}(\mathrm{meq} / \mathrm{l}),(\mathbf{c}) \mathrm{SO}_{4}{ }^{2-}$

$776+\mathrm{HCO}_{3}{ }^{-}(\mathrm{meq} / \mathrm{l})$, (d) Alkalinity $\left(\mathrm{Na}^{+}+\mathrm{K}^{+}\right)$versus $\mathrm{Mg}^{2+}$ (meq/l), (e) TDS versus $\mathrm{Cl}^{-}(\mathrm{mg} / \mathrm{l}),(\mathrm{f}) \mathrm{TDS}(\mathrm{mg} / \mathrm{l})$ 777 versus $\mathrm{Cl}^{-} / \mathrm{Ca}^{2+}(\mathrm{meq} / \mathrm{l})$.

778 Fig. 9. Scatter plots of (a) $\mathrm{Cl}^{-}$versus $\mathrm{Na}^{+}$(mmol/l) (after Li et al., 2013), (b) $\mathrm{Cl}^{-}$versus $\mathrm{Cl}^{-} / \mathrm{HCO}_{3}^{-}$(meq/l)

779 Fig. 10. Dendrogram of hydrogeochemical data using Ward method 


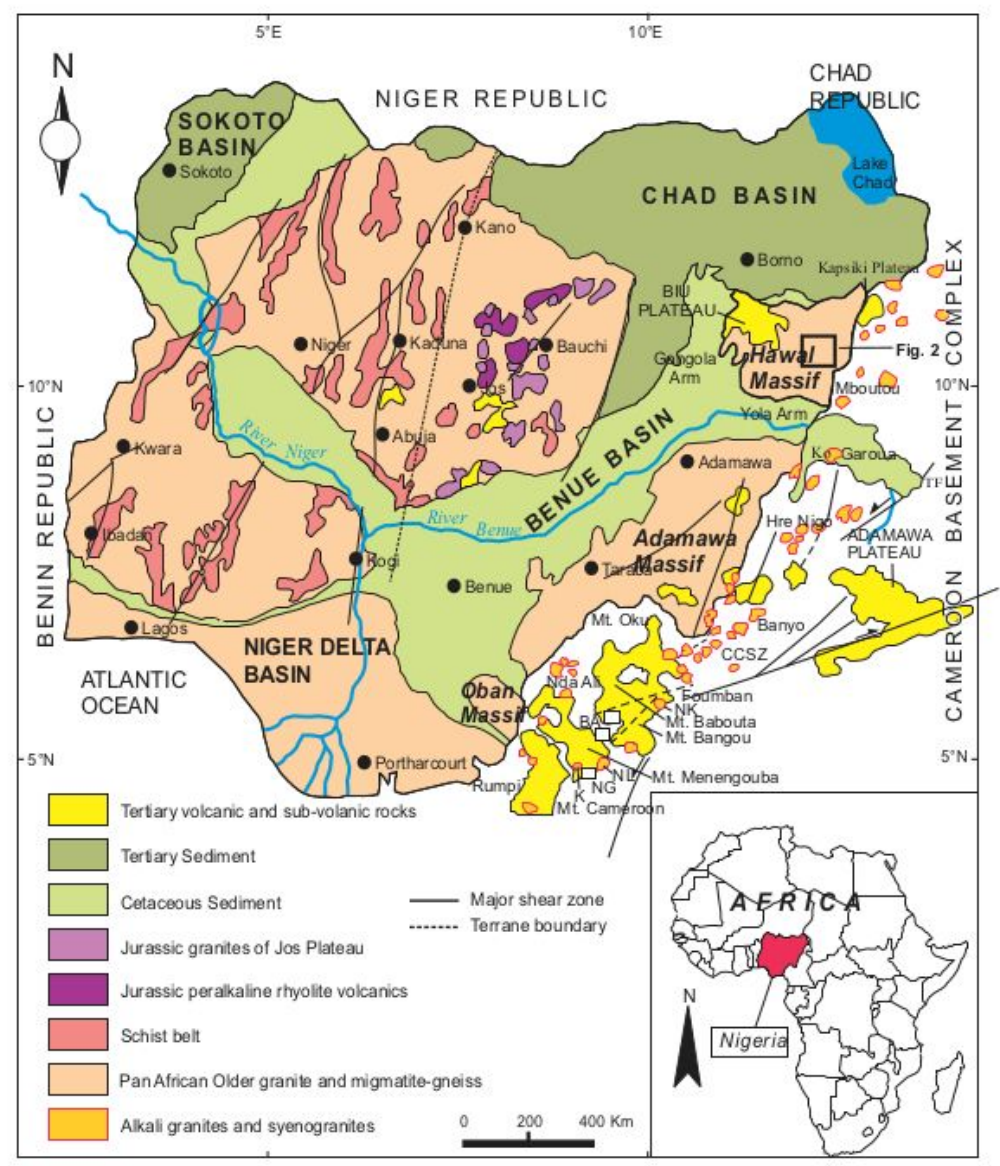

Figure 1

\section{Figure 1}

Regional geological map of Nigeria (after Ferré et al., 1996 and Key et al., 2012). Distribution of rocks within the Cameroon volcanic line (after Ngako et al., 2006). 


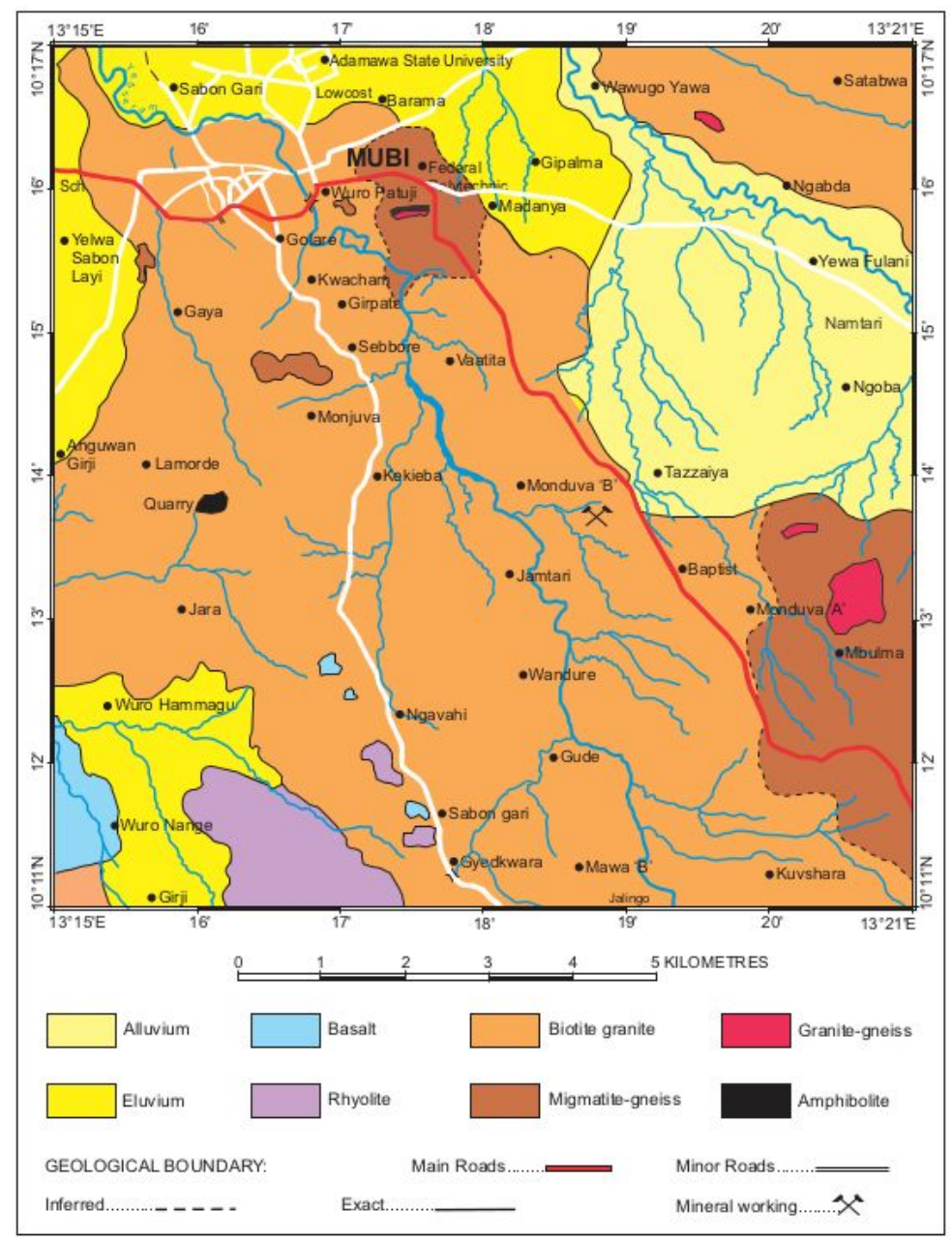

Figure 2

Figure 2

Geological map of the study area. 


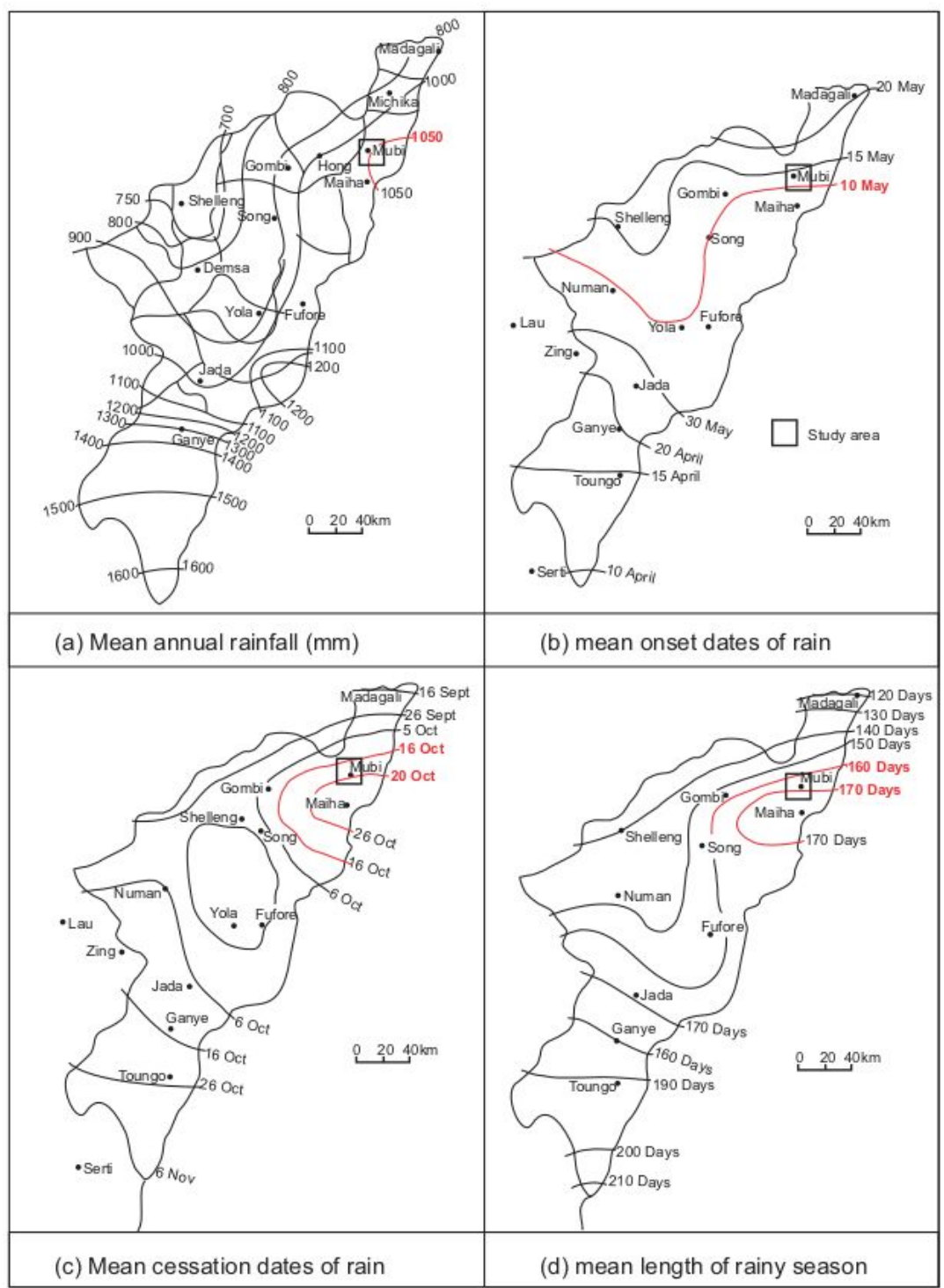

Figure 3

Figure 3

Annual rainfall pattern of the study area (after Adebayo and Tukur, 1999). 


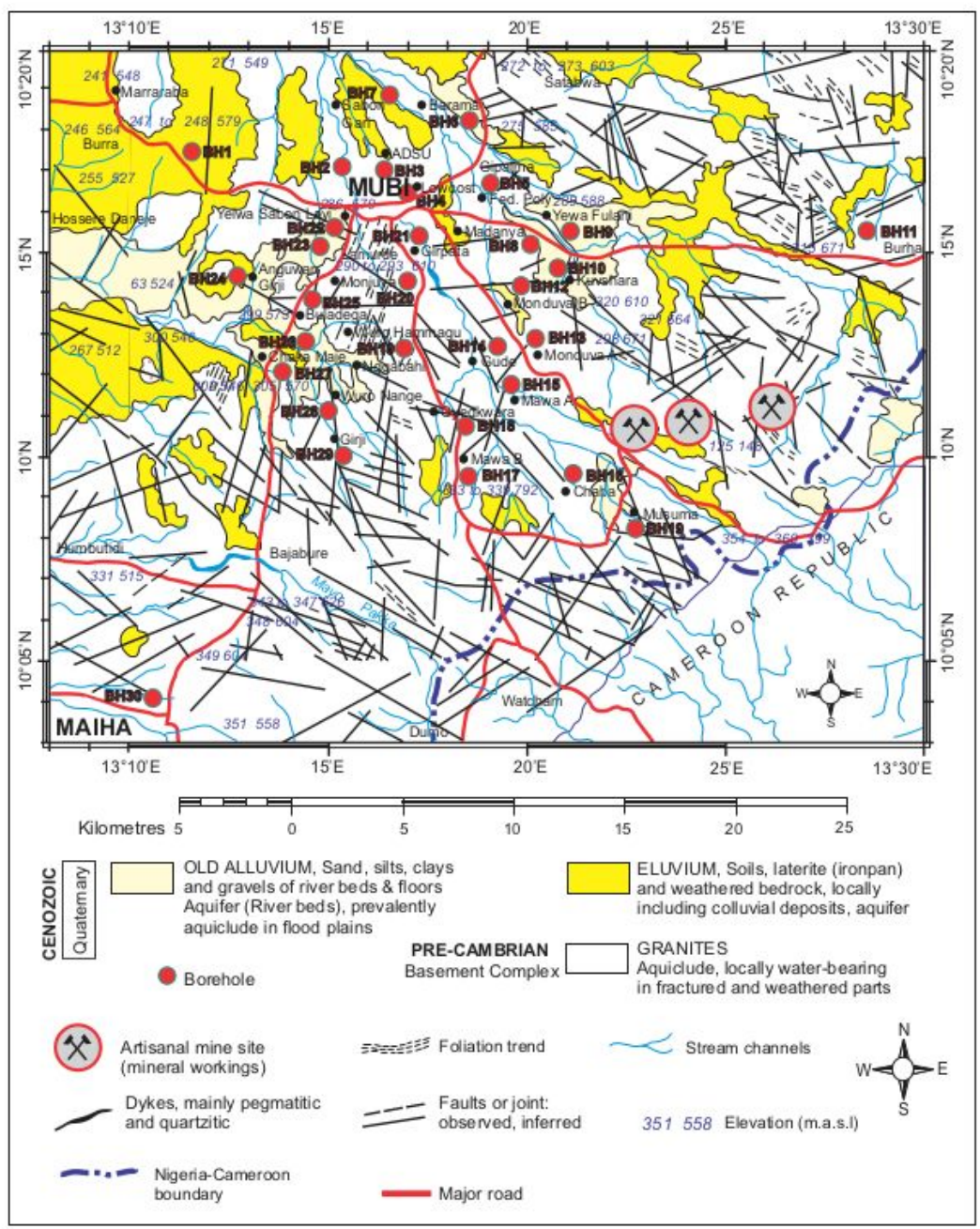

Figure 4

Figure 4

Hydrogeological map of the study area and environs showing the location of boreholes (after Consulint International s.r.I and Consulint Nigeria, 1976). 


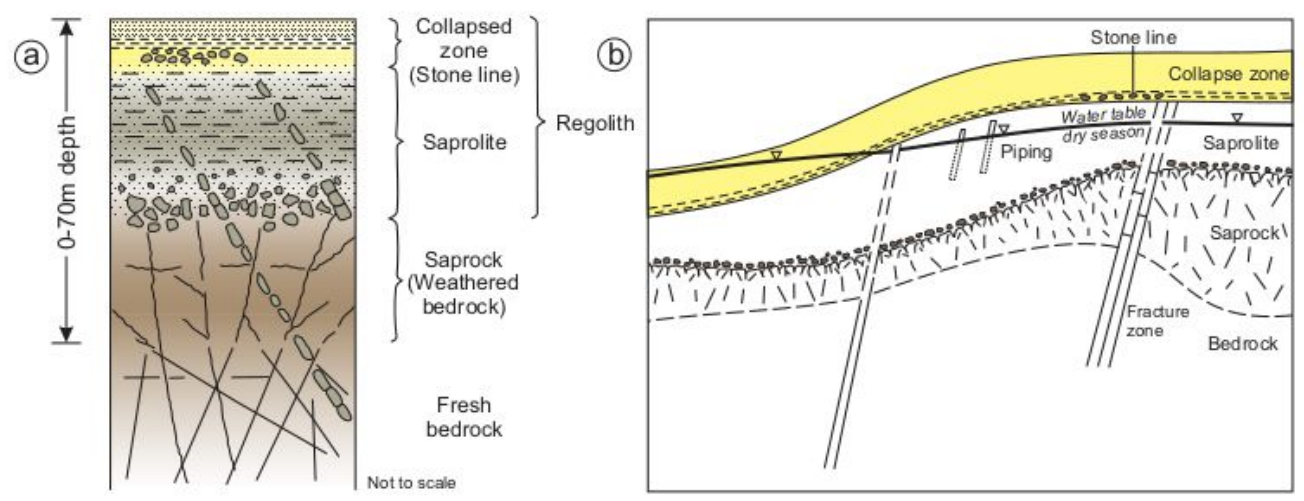

Figure 5

Figure 5

(a) Schematic weathered profile above crystalline basement rocks (after Wright, 1992), (b) Schematic basement aquifer catenary cross section (after Wright, 1992). 

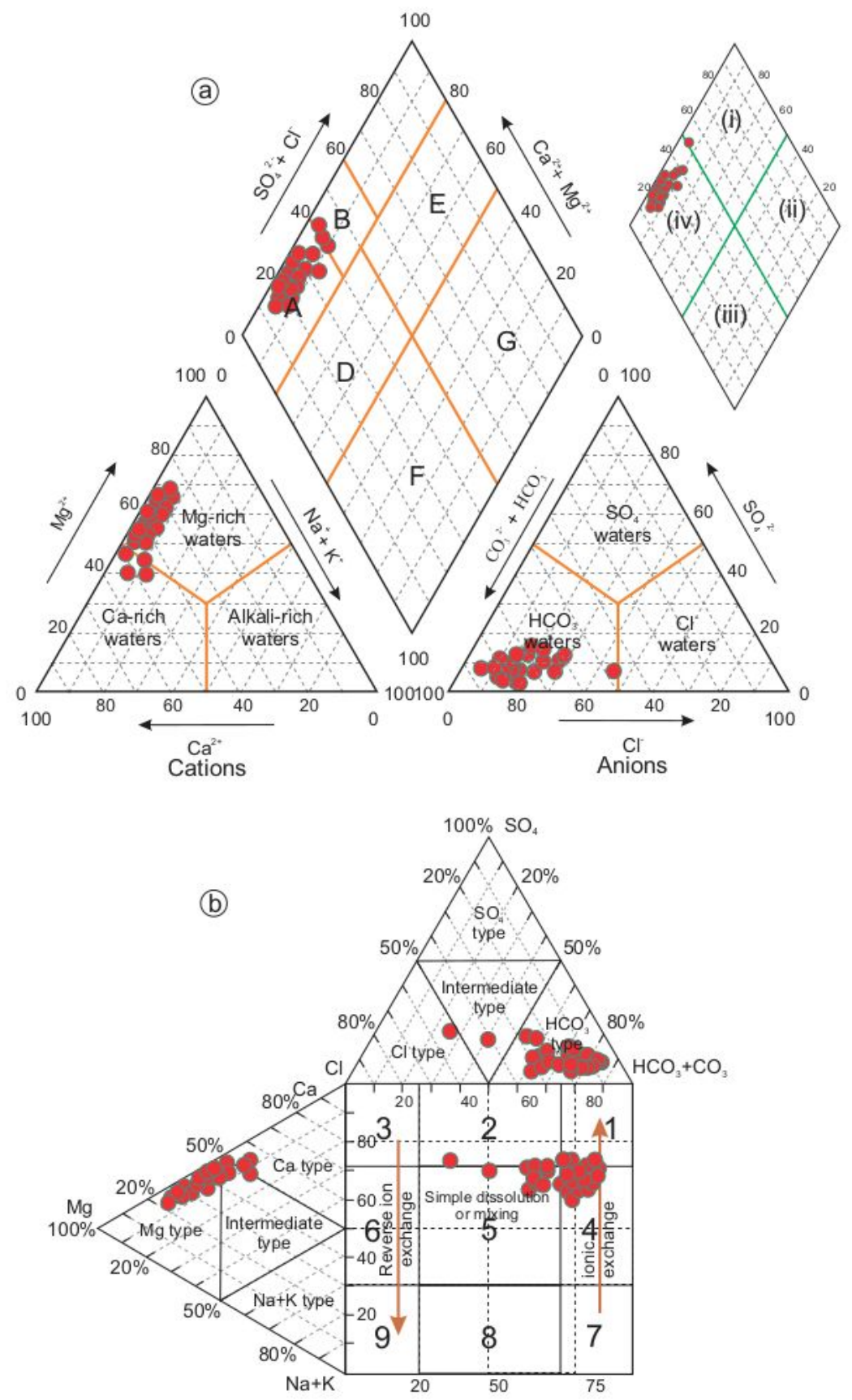

Figure 6

\section{Figure 6}

(a) Piper Trilinear diagram classifying major hydrochemical facies. Divisions in quadrilateral and triangles (after Langguth, 1966), (b) Durov plot depicting hydrochemical processes. Division in the square and two triangles are after Lloyd and Heathcoat (1985) and Singh and Kumar (2015). 

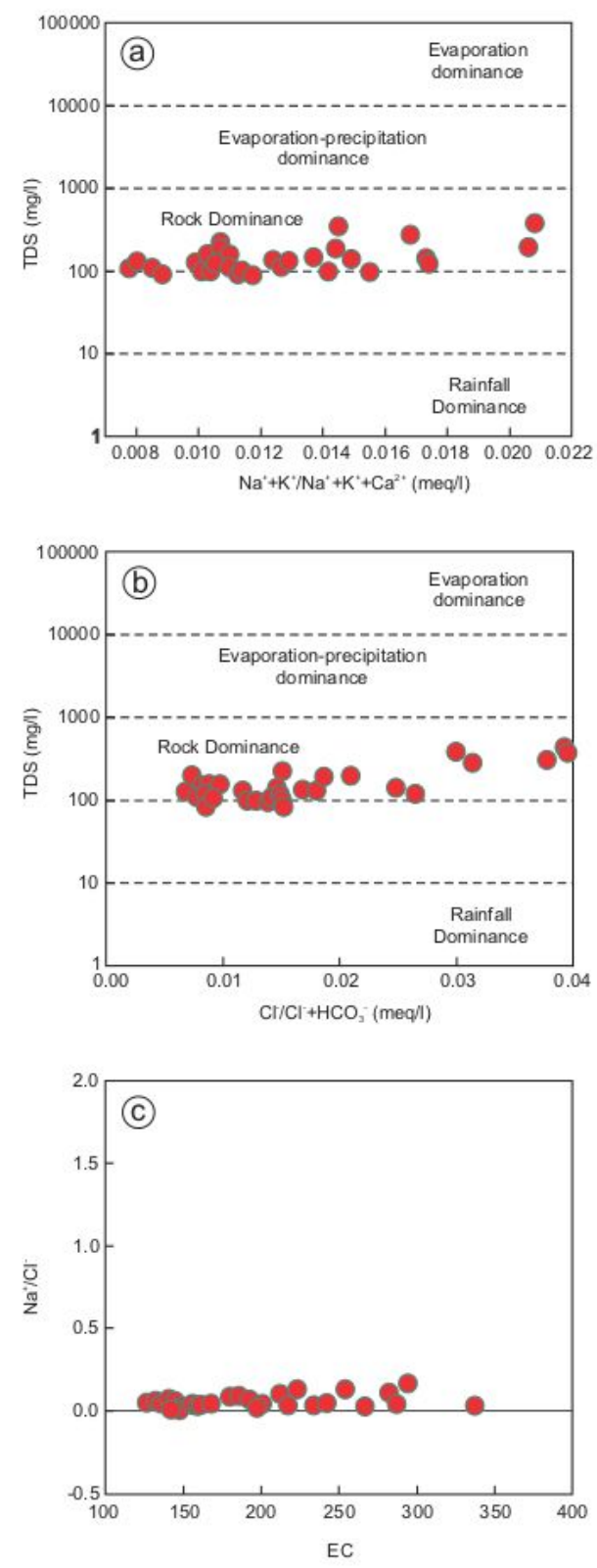

Figure 7

\section{Figure 7}

Gibb's Diagram (a) cation versus TDS, (b) anion versus TDS showing the overriding control of rock dominance (silicate weathering) in the hydrogeochemical system of the area (after Gibbs, 1970), (c) $\mathrm{Na}+/ \mathrm{Cl}$ - vs. EC binary plot to interpret the evaporation/evapotranspiration (after Sahu et al., 2021). 

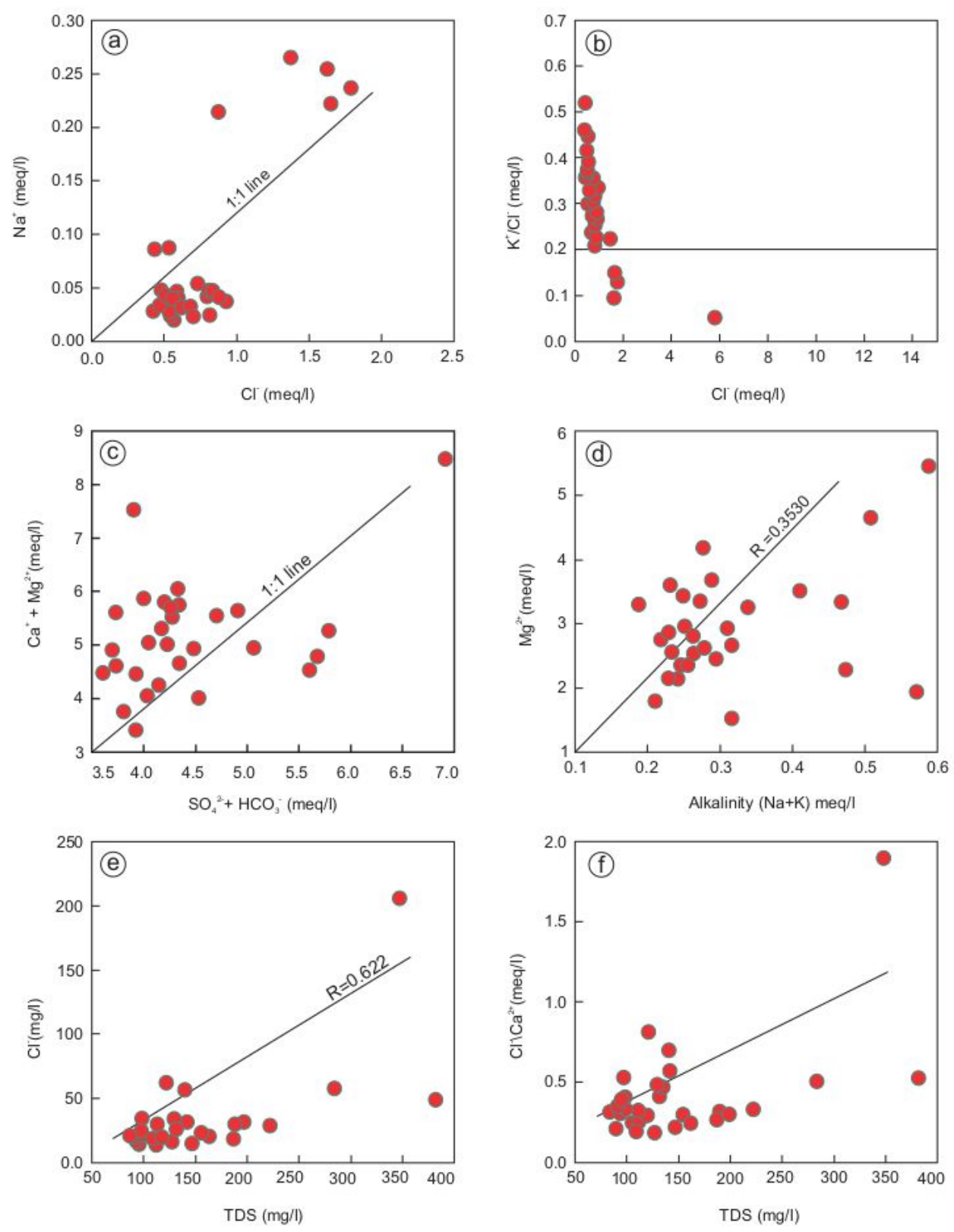

Figure 8

\section{Figure 8}

Scatter plots of cations and anions (a) Cl- versus $\mathrm{Na}+$ (meq/l), (b) Cl- versus $\mathrm{K}-/ \mathrm{Cl}$ - (meq/l), (c) SO42- + HCO3- (meq/l), (d) Alkalinity ( $\mathrm{Na}++\mathrm{K}+$ ) versus Mg2+ (meq/l), (e) TDS versus $\mathrm{Cl}-(\mathrm{mg} / \mathrm{l})$, (f) TDS (mg/l) versus $\mathrm{Cl}-/ \mathrm{Ca} 2+(\mathrm{meq} / \mathrm{l})$. 

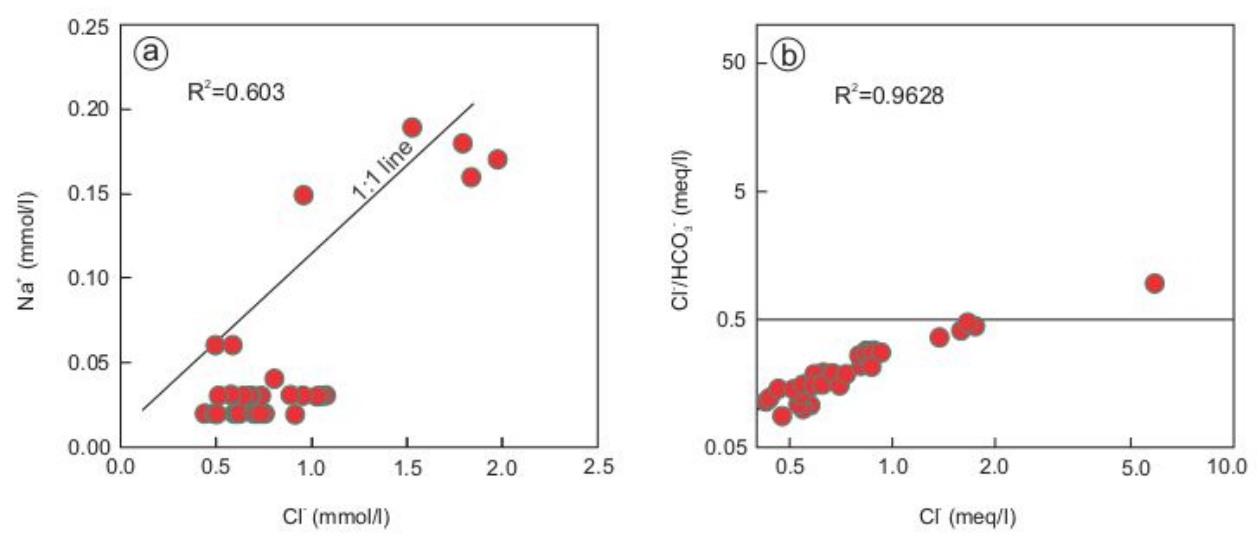

Figure 9

Figure 9

Scatter plots of (a) Cl-versus $\mathrm{Na}+(\mathrm{mmol} / \mathrm{l})$ (after Li et al., 2013), (b) Cl-versus $\mathrm{Cl}-/ \mathrm{HCO}-(\mathrm{meq} / \mathrm{l})$ 


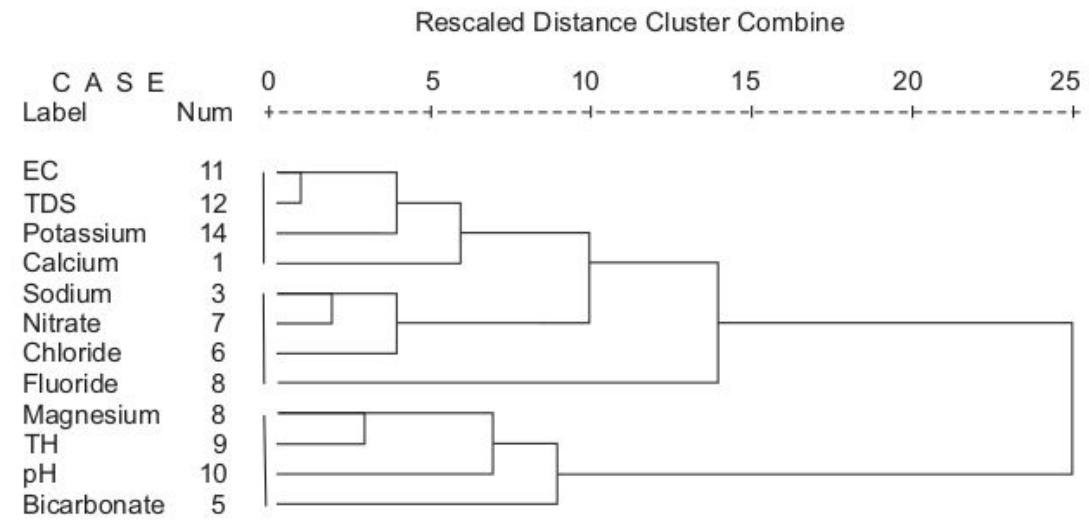

Figure 10

Figure 10

Dendrogram of hydrogeochemical data using Ward method 